\title{
Chiral sulfide-mediated enantioselective epoxidation of aldehydes
}

\author{
Takao Saito,* Daisuke Akiba, Masao Sakairi, Ken Ishikawa, and Takashi Otani \\ Department of Chemistry, Faculty of Science, Tokyo University of Science, Kagurazaka, \\ Shinjuku-ku, Tokyo 162-8601, Japan \\ E-mail: tsaito@ch.kagu.tus.ac.jp
}

Dedicated to Professor Binne Zwanenburg on the occasion of his $70^{\text {th }}$ birthday

(received 23 Oct 03; accepted 11 Dec 03; published on the web 10 Jan 04)

\begin{abstract}
Non-racemic epoxides were prepared via enantioselective Corey-Chaykovsky epoxidation of aromatic, heteroaromatic and cinnamic aldehydes with chiral sulfonium ylides. One-pot epoxidation using aldehydes, alkyl bromides and chiral sulfide in the presence of a base was also investigated. The chiral sulfide was easily synthesized in five steps from $d$-camphor through hetero Diels-Alder reaction as a key step.
\end{abstract}

Keywords: Epoxidation, epoxides, oxiranes, stilbene oxides, sulfides, sulfonium ylides

\section{Introduction}

Epoxides are useful and important synthetic intermediates and found diverse applications in organic synthesis. ${ }^{1}$ Great concern focuses on development of synthetic methods for asymmetric epoxidation, as exemplified by the Sharpless, Katsuki, and Jacobsen olefin oxidations and Darzens approaches using carbonyl compounds. ${ }^{2}$ Chiral sulfonium ylide-mediated enantioselective epoxidation of aldehydes and ketones, an asymmetric version of so-called "Corey-Chaykovsky reaction," has recently begun to receive much attention as an alternative method for asymmetric synthesis of epoxides. ${ }^{4-10}$ The methodology involves the formation of sulfonium ylide which can be in situ generated via essentially two independent routes, viz. (i) alkylation of a sulfide, followed by deprotonation of the resulting sulfonium salt (salt method), ${ }^{4-9}$ and (ii) coupling of a sulfide with a carbenoid (metal carbene) generated in situ from diazo compound or its precursor (e.g. tosyl hydrazone salt). ${ }^{4,10}$ The efficiency of asymmetric induction for the epoxidation undoubtedly depends largely upon chiral sulfides used. In very recent reports, efforts have been made on the synthesis of new chiral sulfides/sulfonium ylides as well as their use in not only epoxidation ${ }^{11}$ but also aziridination ${ }^{12}$ and cyclopropanation. ${ }^{13}$ Thus, information on a variety of new chiral sulfides and/or sulfonium ylides regarding the efficiency on yields and stereoselectivities for these reactions is necessary to understand chemistry from the synthetic and mechanistic points of view. ${ }^{14}$ The attractive advantages of exploiting natural $d$-camphor in 
asymmetric synthesis are its relatively inexpensive and easy availability, potent transformation ability, and promising asymmetric induction due to the topological differentiation efficiency apparently by virtue of the rigid framework of its derivatives. ${ }^{15}$ With this in mind, we envisioned that camphor framework-connected cyclic chiral sulfide would be of high potential as an asymmetric induction mediator in the epoxidation. In this full paper we describe our results in the enantiomeric Corey-Chaykovsky epoxidation with optimization of various factors and reaction conditions employing such camphor-derived homochiral tricyclic sulfide $\mathbf{1}^{16}$

\section{Results and Discussion}

\section{Preparation of Chiral Sulfide 1}

The sulfide 1 was readily prepared from natural $d$-camphor in five steps in 50-60\% overall yields (Scheme 1). The key step was the highly exo selective and complete $\pi$-face-selective hetero Diels-Alder reaction of 3 -arylmethylenecamphorthiones $\mathbf{3}$ with methyl acrylate. ${ }^{17}$ The stereochemistry of cycloadducts 4 was unequivocally established by X-ray crystallographic analysis of $\mathbf{4}(\mathrm{Ar}=\mathrm{Ph})$ and ${ }^{1} \mathrm{H}-\mathrm{NMR}$ spectroscopic study. ${ }^{17}$ Although cycloadducts $\mathbf{4}$ or alcohols 5 essentially neither reacted with benzyl bromide to give sulfonium salts nor mediated epoxidation with aldehydes in the presence of a base, it was hoped that chiral sulfide $\mathbf{1}$ obtained by highly $\pi$-face-selective hydrogenation of $\mathbf{5}$ would act efficiently as a mediator in the epoxidation. Indeed, sulfide 1 worked well in the epoxidation by both methods, (A) the epoxidation of aldehydes using sulfonium salt prepared in advance and (B) the one-pot epoxidation starting from aldehyde, alkyl halide and sulfide $\mathbf{1}$ in the presence of a base.
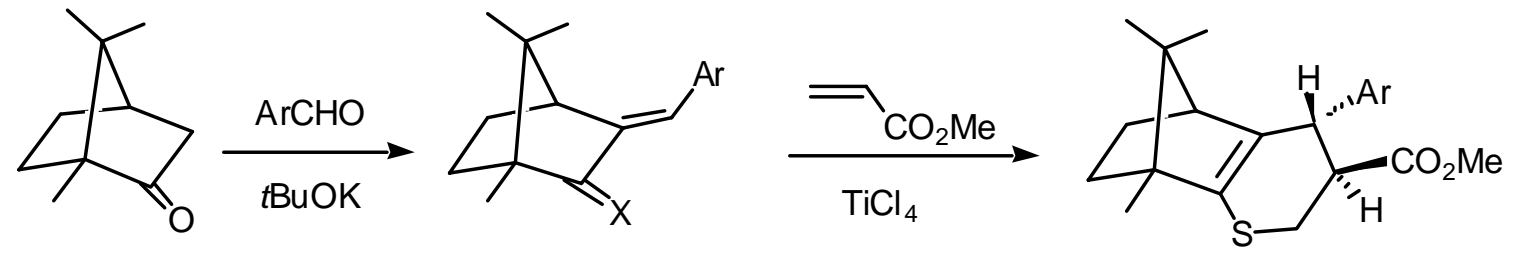

$$
\begin{gathered}
\mathrm{Ar}= \\
=\mathrm{Ph}-\mathrm{Tol} \\
\mathrm{Ph}
\end{gathered}
$$

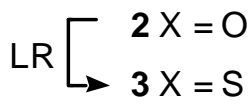

4

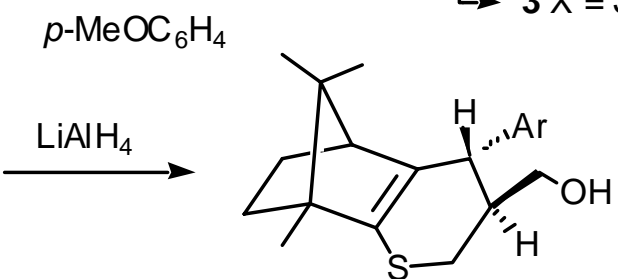

5

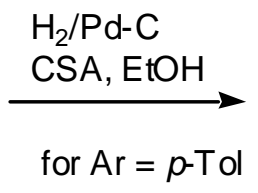

for $\mathrm{Ar}=p$-Tol

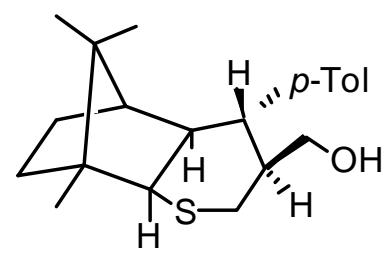

1

Scheme 1 


\section{(A) Epoxidation using sulfonium salt}

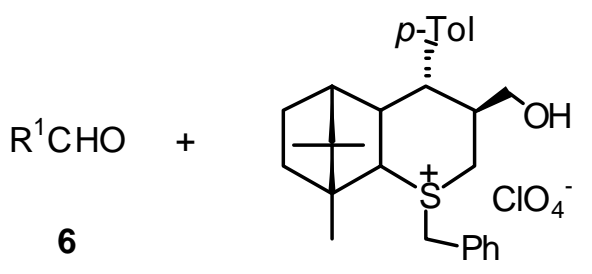

$7 a$

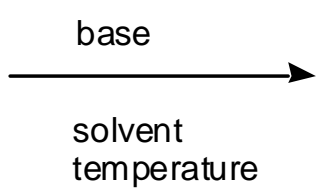

temperature

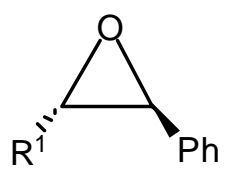

8

Scheme 2. For specification of the substituent $\mathrm{R}^{1}$, see Table 6 .

Sulfonium perchlorate 7a, which was prepared by the reaction of chiral sulfide $\mathbf{1}$ with benzyl bromide and silver perchlorate, was allowed to react with aldehyde $6 \mathbf{b}\left(\mathrm{R}^{1}=p-\mathrm{NO}_{2} \mathrm{C}_{6} \mathrm{H}_{4}\right)$ as a model reaction to find first a suitable base under the conditions (Table 1). In all the cases trans epoxide (trans-8b) was obtained as the major product with enantiomeric excess (ee) of 71-79 \%. Among the bases used $\mathrm{KOH}$ seems to be the best of choice in the balance of yield and enantioselectivity.

Table 1. Effects of base in epoxidation of $\mathbf{6 b}\left(\mathrm{R}^{1}=p-\mathrm{NO}_{2} \mathrm{C}_{6} \mathrm{H}_{4}\right)$ with 7a to afford $\mathbf{8} \mathbf{b}{ }^{\mathrm{a}}$

\begin{tabular}{lllll}
\hline Run & Base (equiv.) & Yield $(\%)^{\mathrm{b}}$ & Trans: $^{\text {cis }^{\mathrm{c}}}$ & ${\text { Trans ee }(\%)^{\mathrm{c}}}^{\mathrm{c}}$ \\
\hline 1 & KOH (1.2) & 95 & $>99:<1$ & 79 \\
2 & $t$-BuOK (1.2) & 57 & $>99:<1$ & 71 \\
3 & $n-\operatorname{BuLi}(1.5)$ & 33 & $>99:<1$ & 79 \\
\hline
\end{tabular}

${ }^{\mathrm{a}}$ Reactions were carried out in THF at $-78^{\circ} \mathrm{C}$ for $6 \mathrm{~h}$ using 1.0 equiv. 6a and 1.2 equiv. 7a. ${ }^{\mathrm{b}}$ Yields based on consumed amounts of $p$-nitrobenzaldehyde (6b). ${ }^{c}$ Determined by HPLC [Chiralcel OD, i-PrOH-hexane (1:30)].

Table 2. Epoxidation of $\mathbf{6 b}\left(\mathrm{R}^{1}=p-\mathrm{NO}_{2} \mathrm{C}_{6} \mathrm{H}_{4}\right)$ with $\mathbf{7 a}$ to afford $\mathbf{8 b}$ under various reaction conditions ${ }^{\text {a }}$

\begin{tabular}{|c|c|c|c|c|}
\hline Run & Reaction conditions & Yield $(\%)^{b}$ & Trans : $\operatorname{cis}^{\mathrm{c}}$ & Trans ee $(\%)^{\mathrm{c}}$ \\
\hline 1 & $\mathrm{CH}_{2} \mathrm{Cl}_{2}$, r. temp, $2 \mathrm{~h}$ & 99 & $97: 3$ & 27 \\
\hline 2 & THF, r. temp, $2 \mathrm{~h}$ & 99 & $97: 3$ & 18 \\
\hline 3 & $\mathrm{THF}, 0{ }^{\circ} \mathrm{C}, 3 \mathrm{~h}$ & 99 & $98: 2$ & 35 \\
\hline 4 & $\mathrm{THF},-15^{\circ} \mathrm{C}, 5 \mathrm{~h}$ & 99 & $98: 2$ & 56 \\
\hline 5 & $\mathrm{THF},-40{ }^{\circ} \mathrm{C}, 6 \mathrm{~h}$ & $50[98]$ & $99: 1$ & 77 \\
\hline 6 & $\mathrm{THF},-78^{\circ} \mathrm{C}, 6 \mathrm{~h}$ & 31 [99] & $>99:<1$ & 79 \\
\hline 7 & $\mathrm{MeCN}$, r. temp, $1.5 \mathrm{~h}$ & 99 & $97: 3$ & 41 \\
\hline 8 & $\mathrm{MeCN}, 0{ }^{\circ} \mathrm{C}, 2 \mathrm{~h}$ & 99 & $97: 3$ & 62 \\
\hline
\end{tabular}


Table 2. Continued

\begin{tabular}{lllll}
\hline Run & Reaction conditions & Yield $(\%)^{\mathrm{b}}$ & Trans : cis $^{\mathrm{c}}$ & Trans ee $(\%)^{\mathrm{c}}$ \\
\hline 9 & $\mathrm{MeCN},-15{ }^{\circ} \mathrm{C}, 3 \mathrm{~h}$ & 99 & $98: 2$ & 71 \\
10 & $\mathrm{MeCN},-40{ }^{\circ} \mathrm{C}, 9 \mathrm{~h}$ & $89[98]$ & $99: 1$ & 81 \\
11 & $t$-BuOH, r. temp, $1.5 \mathrm{~h}$ & 99 & $82: 18$ & 80 \\
12 & THF-MeCN $(2: 1),-78{ }^{\circ} \mathrm{C}, 9 \mathrm{~h}$ & $43[98]$ & $99: 1$ & 79 \\
13 & THF-t-BuOH $(2: 1),-78{ }^{\circ} \mathrm{C}, 9 \mathrm{~h}$ & $37[98]$ & $99: 1$ & 79 \\
14 & MeCN-t-BuOH $(2: 1),-40{ }^{\circ} \mathrm{C}, 9 \mathrm{~h}$ & $89[98]$ & $94: 6$ & 82 \\
\hline
\end{tabular}

${ }^{\mathrm{a}} \mathrm{KOH}$ (1.2 equiv) was used as a base. ${ }^{\mathrm{b}}$ Isolated yields. In square brackets yields based on consumed amounts of $\mathbf{6 b} .{ }^{\mathrm{c}}$ Determined by HPLC [Chiralcel OD, i-PrOH-hexane (1:30)].

Then, we explored the same reaction in the presence of $\mathrm{KOH}$ to optimize reaction conditions by varying solvent, temperature and reaction time. The results are shown in Table 2 . In every case high trans:cis selectivity was obtained. As the reaction temperature becomes lower (runs 26 and 7-10), the trans:cis selectivity and the enantioselectivity both become higher in the same solvent, as expected. As for the solvent effect on the enantioselectivity and the diastereoselectivity, higher ee's values could be attained in more polar solvents than in less polar solvents, whereas the reverse propensity was observed for the diastereoselectivity. This effect would not simply arise from solubility of the sulfonium perchlorate 7a because 7a is soluble enough in either solvent under the conditions applied. Quite recently, an excellent rationale has been proposed by Aggarwal et al. to explain origins of both of the stereoselectivities by unraveling the mechanism. ${ }^{10 a}$ This tendency of the solvent effect was also observed in the reaction of benzaldehyde (6a) to give epoxide $\mathbf{8 a}$ (Table 3).

Table 3. Effects of solvent in epoxidation of $\mathbf{6 a}\left(\mathrm{R}^{1}=\mathrm{Ph}\right)$ with $7 \mathbf{a}$ to afford $\mathbf{8 a}{ }^{\mathrm{a}}$

\begin{tabular}{lllll}
\hline Run & Solvent & ${\text { Yield }(\%)^{\mathrm{b}}}$ & ${\text { Trans }: \text { cis }^{\mathrm{c}}}$ & ${\text { Trans ee }(\%)^{\mathrm{c}}}^{\mathrm{c}}$ \\
\hline 1 & $\mathrm{CH}_{2} \mathrm{Cl}_{2}$ & $52[86]$ & $99: 1$ & 22 \\
2 & $\mathrm{MeCN}$ & $80[94]$ & $95: 5$ & 34 \\
3 & $t-\mathrm{BuOH}$ & $85[>99]$ & $94: 6$ & 69 \\
\hline
\end{tabular}

${ }^{a}$ Reactions were carried out at room temperature $\left(22-25^{\circ} \mathrm{C}\right)$ for 2 days using $\mathrm{KOH}$ (1.2 equiv) as a base. ${ }^{\mathrm{b}}$ Isolated yields. In square brackets yields based on consumed amounts of benzaldehyde (6a). ${ }^{\mathrm{c}}$ Determined by HPLC [Chiralcel OD, i-PrOH-hexane (1:100)]. 
Table 4. Effects of water added as a co-solvent in epoxidation of $\mathbf{6 b}\left(\mathrm{R}^{1}=p-\mathrm{NO}_{2} \mathrm{C}_{6} \mathrm{H}_{4}\right)$ with $7 \mathbf{a}$ to afford $\mathbf{8 b}{ }^{\text {a }}$

\begin{tabular}{|c|c|c|c|c|}
\hline Run & Reaction conditions (ratio in volume) & Yield $(\%)^{b}$ & Trans : $\operatorname{cis}^{\mathrm{c}}$ & Trans ee $(\%)^{\mathrm{c}}$ \\
\hline 1 & $\mathrm{MeCN}$, room temp, $1.5 \mathrm{~h}$ & 99 & $97: 3$ & 41 \\
\hline 2 & $\mathrm{MeCN}-\mathrm{H}_{2} \mathrm{O}(9: 1)$, room temp, $2 \mathrm{~h}$ & 99 & $88: 12$ & 76 \\
\hline 3 & $\mathrm{MeCN}-\mathrm{H}_{2} \mathrm{O}(5: 5)$, room temp, $2 \mathrm{~h}$ & 99 & $80: 20$ & 79 \\
\hline 4 & $\mathrm{MeCN}-\mathrm{H}_{2} \mathrm{O}(3: 7)$, room temp, $2 \mathrm{~h}$ & 99 & $78: 22$ & 80 \\
\hline 5 & $\mathrm{MeCN}-\mathrm{H}_{2} \mathrm{O}(1: 9)$, room temp, $2 \mathrm{~d}$ & 85 & $76: 24$ & 80 \\
\hline 6 & $\mathrm{MeCN}-\mathrm{H}_{2} \mathrm{O}(7: 3),-40{ }^{\circ} \mathrm{C}, 9 \mathrm{~h}$ & 69 [98] & $92: 8$ & 86 \\
\hline $7^{\mathrm{d}}$ & $\mathrm{MeCN}-\mathrm{H}_{2} \mathrm{O}(7: 3),-40{ }^{\circ} \mathrm{C}, 9 \mathrm{~h}$ & $32[97]$ & $97: 3$ & 91 \\
\hline 8 & $\mathrm{H}_{2} \mathrm{O}$, r. temp, $4 \mathrm{~d}$ & 18 & $69: 31$ & 80 \\
\hline 9 & $t-\mathrm{BuOH}, \mathrm{r}$. temp, $1.5 \mathrm{~h}$ & 99 & $82: 18$ & 80 \\
\hline 10 & $t-\mathrm{BuOH}-\mathrm{H}_{2} \mathrm{O}(9: 1)$, room temp, $2 \mathrm{~h}$ & 99 & $76: 24$ & 83 \\
\hline 11 & $t-\mathrm{BuOH}-\mathrm{H}_{2} \mathrm{O}(5: 5)$, room temp, $2 \mathrm{~h}$ & 99 & $70: 30$ & 84 \\
\hline
\end{tabular}

${ }^{\mathrm{a}} \mathrm{KOH}$ (1.2 equiv) was used as a base. ${ }^{\mathrm{b}}$ Isolated yields. In square brackets yields based on consumed amounts of $\mathbf{6 b} .{ }^{\mathrm{c}}$ Determined by HPLC [Chiralcel OD, i-PrOH-hexane (1:30)]. ${ }^{\mathrm{d}} p$ Chlorobenzaldehyde (6c) was used instead of $\mathbf{6 b}$.

Since in more polar solvents higher enantioselectivity was obtained as described above, we further examined the reaction by adding water as a co-solvent. The results are summarized in Table 4. As the ratio water/solvent increases (runs 1-5 and 9-11), the enantioselectivity goes up, while the trans:cis ratio gradually decreases. ${ }^{18}$ At a temperature of $-40{ }^{\circ} \mathrm{C}$ in $\mathrm{MeCN}-\mathrm{H}_{2} \mathrm{O}(7: 3)$ (runs 6 and 7), the highest ee's of $86 \%$ and 91\% were achieved albeit in lower isolated yield. In the reaction in the medium of water (run 8) equally good enantioselectivity of $80 \%$ ee was obtained, though the isolated yield was very low. The low yield may be due to sparing solubility of the aldehyde $\mathbf{6}$ and/or generated sulfonium ylide into the water, since considerable amounts of 6 unreacted was recovered.

Furthermore, effects of the counter anion of the sulfonium salts for the epoxidation were also checked. As a result, no significant differences of the yields and both the stereoselectivities were observed (Table 5).

Table 5. Effects of the counter anion of 7 in epoxidation of $\mathbf{6 b}\left(\mathrm{R}^{1}=p-\mathrm{NO}_{2} \mathrm{C}_{6} \mathrm{H}_{4}\right)$ to afford $\mathbf{8 b}{ }^{\mathrm{a}}$

\begin{tabular}{|c|c|c|c|c|c|c|}
\hline Run & 7 & Counter anion & Time (h) & Yield $(\%)^{\mathrm{b}}$ & Trans : cis $^{\mathrm{c}}$ & Trans ee $(\%)^{\circ}$ \\
\hline 1 & $\mathbf{a}$ & $\mathrm{ClO}_{4}^{-}$ & 1.5 & 99 & $88: 12$ & 80 \\
\hline 2 & $\mathbf{b}$ & $\mathrm{TfO}^{-}$ & 2 & 99 & $88: 12$ & 78 \\
\hline 3 & $\mathbf{C}$ & $\mathrm{BF}_{4}$ & 3 & 99 & $88: 12$ & 76 \\
\hline 4 & d & $\mathrm{Br}^{-}$ & 6 & 97 & $87: 13$ & 77 \\
\hline 5 & e & $\mathrm{I}^{-}$ & 6 & 98 & $84: 16$ & 78 \\
\hline
\end{tabular}

${ }^{a}$ Reactions were carried out in $t-\mathrm{BuOH}$ at room temperature $\left(22-25{ }^{\circ} \mathrm{C}\right)$ using $\mathrm{KOH}(1.2$ equiv. $)$ as a base. ${ }^{b}$ Isolated yields. ${ }^{c}$ Determined by HPLC [Chiralcel OD, i-PrOH-hexane (1:30)]. 
In order to examine the generality of this epoxidation, the reaction of 7a with aldehydes 6 bearing a variety of substituents $\left(\mathrm{R}^{1}\right)$ was performed under the conditions optimized above in terms of balance of the reactivity (yield) and the diastereo- and enantioselectivities. The results are shown in Table 6. Apparently, the electron-withdrawing substituents accelerate the reaction, whereas the electron-repelling ones retard the reaction. By using 2.0 equimolar amounts of 7a, the results could be somewhat improved (runs $\mathbf{d}$ and $\mathbf{e}$ ).

It is noteworthy that chiral sulfide 1 was recovered enantiomerically pure in good yields in the cases that good isolated yields of epoxides 8 were obtained (Tables 2 -6) and could be reused.

By employing this epoxidation method, trans-oxiranylcarboxamide 10 could be synthesized in high trans : cis selectivity with fairly good enantioselectivity (Scheme 3, Table 7), which are comparable to those in recent report. ${ }^{5 a, 11 \mathrm{e}}$ However, it was found that an electron-withdrawing group such as a nitro group in aldehyde $\mathbf{6}$ is necessary to activate the formyl group in the epoxidation with this amide-stabilized sulfonium ylide generated from salt 9.

Table 6. Epoxidation of $\mathbf{6}$ bearing a variety of substituents with 7a to afford $\mathbf{8}^{\text {a }}$

\begin{tabular}{|c|c|c|c|c|c|c|c|}
\hline Run & $\mathrm{R}^{1}$ & Time (h) & Yield $(\%)^{b}$ & Trans : $\operatorname{cis}^{\mathrm{c}}$ & Trans ee $(\%)^{\mathrm{c}}$ & & Cis ee $(\%)^{\mathrm{c}}$ \\
\hline $\mathrm{a}$ & $\mathrm{Ph}$ & 48 & 85 & $94: 6$ & 69 & {$[\mathrm{~S}, \mathrm{~S}]$} & 69 \\
\hline$b$ & $p-\mathrm{NO}_{2} \mathrm{C}_{6} \mathrm{H}_{4}$ & 1.5 & 99 & $82: 18$ & 80 & {$[\mathrm{~S}, \mathrm{~S}]$} & 99 \\
\hline$c^{d}$ & $p-\mathrm{ClC}_{6} \mathrm{H}_{4}$ & 4 & $99(32)$ & $92: 8(97: 3)$ & $70(91)$ & {$[\mathrm{S}, \mathrm{S}]$} & nd \\
\hline$d^{e}$ & $p$-Tol & 96 [48] & 88 [89] & $93: 7[93: 7]$ & $56[62]$ & {$[\mathrm{S}, \mathrm{S}]$} & nd \\
\hline$e^{e}$ & $p-\mathrm{MeOC}_{6} \mathrm{H}_{4}$ & 96 [48] & 44 [82] & $96: 4[95: 5]$ & $62[68]$ & {$[\mathrm{S}, \mathrm{S}]$} & nd \\
\hline $\mathrm{f}$ & 2-Naphtyl & 24 & 99 & $89: 11$ & 74 & {$[\mathrm{~S}, \mathrm{~S}]$} & nd \\
\hline $\mathrm{g}$ & $\beta$-Styryl & 18 & 95 & $95: 5$ & 80 & {$[\mathrm{~S}, \mathrm{~S}]$} & nd \\
\hline $\mathrm{h}$ & 2-Furyl & 3 & 96 & $82: 18$ & 80 & {$[\mathrm{~S}, \mathrm{R}]$} & 80 \\
\hline $\mathrm{i}$ & 2-Thienyl & 3 & 95 & $94: 6$ & 70 & {$[\mathrm{~S}, \mathrm{R}]$} & 63 \\
\hline $\mathrm{j}$ & 2-Pyridyl & 2 & 99 & $68: 32$ & 56 & {$[\mathrm{~S}, \mathrm{~S}]$} & 57 \\
\hline
\end{tabular}

${ }^{\mathrm{a}}$ Reactions were carried out in $t-\mathrm{BuOH}$ at room temperature $\left(22-25{ }^{\circ} \mathrm{C}\right)$ using $\mathrm{KOH}(1.2$ equiv. $)$ as a base. ${ }^{b}$ Isolated yields. ${ }^{c}$ Determined by HPLC [Chiralcel OD or AD, i-PrOH-hexane (1:20200) or EtOH-hexane (1:20-300)]. The absolute configuration of trans isomers was assigned by comparison of the (-) sign of specific rotation with literature data or by assumption. ${ }^{\mathrm{d}}$ In parentheses values taken from run 7 in Table $4 .{ }^{\mathrm{e}}$ In square brackets values when 2.0 equiv. 7a was used.
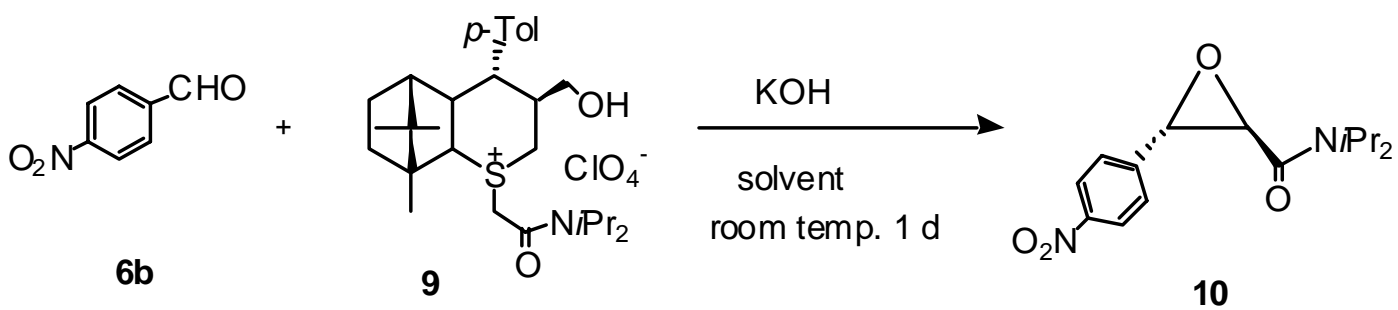

Scheme 3 
Table 7. Enantioselective synthesis of trans-oxiranylcarboxamide $\mathbf{1 0}$ by epoxidation of $\mathbf{6 b}$ with $9^{\text {a }}$

\begin{tabular}{lllll}
\hline Run & Solvent & Yield $(\%)^{\mathrm{b}}$ & Trans $: \operatorname{cis}^{\mathrm{c}}$ & ${\text { Trans ee }(\%)^{\mathrm{c}}}^{\mathrm{c}}$ \\
\hline 1 & $\mathrm{CH}_{2} \mathrm{Cl}_{2}$ & 41 & $>99:<1$ & 50 \\
2 & $\mathrm{MeCN}$ & 68 & $>99:<1$ & 58 \\
3 & $t-\mathrm{BuOH}$ & 50 & $>99:<1$ & 55 \\
\hline
\end{tabular}

${ }^{a}$ Reactions were carried out using 1.0 equiv. $6 \mathbf{b}$ and 1.2 equiv. 9 in the presence of 1.2 equiv. KOH. ${ }^{b}$ Isolated yields. ${ }^{c}$ Determined by HPLC [Chiralcel AS, EtOH-hexane (1:50)].

(B) One-pot epoxidation of aldehyde with alkyl bromide and sulfide 1
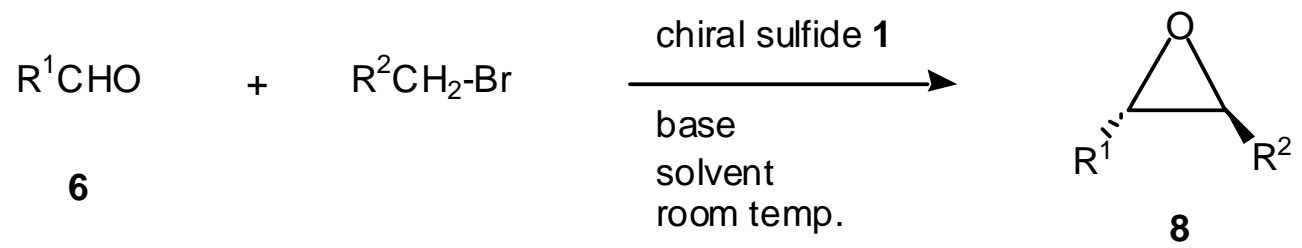

\section{Scheme 4}

Establishing the method (A) using sulfonium salt 7 or 9 prepared beforehand, we next performed three-component one-pot epoxidation of $\mathbf{6}$ with alkyl bromide and chiral sulfide $\mathbf{1}$. A model reaction using benzaldehyde 6a (1.0 equiv), benzyl bromide (3.0 equiv) and chiral sulfide 1 (1.0 equiv) in acetonitrile under the conditions furnished the desired epoxide 8a in $72 \%$ yield with high diastereoselectivity (trans: cis $=96: 4)$ and with moderate enantioselectivity (56\% ee) of the trans isomer, when $\mathrm{K}_{2} \mathrm{CO}_{3}$ was used as a base (Table 8, run 1). $\mathrm{Cs}_{2} \mathrm{CO}_{3}$ can also be a candidate as a base. Encouraged by this result, we next screened solvents for better stereoselectivities (Table 9). Among the solvents used, the reaction in $t$-butyl alcohol showed the best enantioselectivity of $71 \%$ ee of the trans isomer albeit in lower isolated yield and with somewhat decreased diastereoselectivity (run 4). The reaction in tetrahydrofuran or acetone gave only a trace amount of epoxide 8a. Acetonitrile and $t$-butyl alcohol can be the solvent of choice for diastereo- and enantioselectivities, whereas water-containing acetonitrile was less effective in contrast to the above results in Table 4. At a higher temperature of $83{ }^{\circ} \mathrm{C}$ the reaction was indeed accelerated $(2 \mathrm{~h}$, in $t-\mathrm{BuOH})$ but the enantioselectivity of trans isomer was depressed to $44 \%$ ee. 
Table 8. Effects of base in one-pot epoxidation to afford $\mathbf{8 a}{ }^{\text {a }}$

\begin{tabular}{lllll}
\hline Run & Base $^{\mathrm{a}}$ & Yield $/ \%{ }^{\mathrm{b}}$ & ${\text { Trans }: \text { cis }^{\mathrm{c}}}$ & ${\text { Trans ee } / \%{ }^{\mathrm{c}}}^{\mathrm{N}}$ \\
\hline 1 & $\mathrm{~K}_{2} \mathrm{CO}_{3}$ & $72[99]$ & $96: 4$ & 56 \\
$2^{\mathrm{d}}$ & $\mathrm{Cs}_{2} \mathrm{CO}_{3}$ & 99 & $97: 3$ & 43 \\
3 & $\mathrm{NaH}$ & $25[99]$ & $92: 8$ & 32 \\
4 & $\mathrm{KOH}$ & trace & - & - \\
\hline
\end{tabular}

${ }^{a}$ Reactions were carried out in $\mathrm{MeCN}$ at room temperature for $\mathbf{4}$ days using 1.0 equiv. 6a, 3.0 equiv. benzyl bromide and 1.0 equiv. 1 in the presence of a base (3.0 equiv.). ${ }^{b}$ Isolated yields. In square brackets, yields based on consumed amounts of benzaldehyde $6 \mathbf{6 a}^{\mathrm{c}}{ }^{\mathrm{D}}$ Determined by HPLC [Chiralcel OD, i-PrOH-hexane (1:100)]. The absolute configuration was assigned [S,S] by comparison of the sign (-) of specific rotation with the literature data. ${ }^{\mathrm{d}}$ For 1 day.

Table 9. Effects of solvent in one-pot epoxidation to afford $\mathbf{8} \mathbf{a}^{\text {a }}$

\begin{tabular}{lllll}
\hline Run & Solvent & Yield $/ \%{ }^{b}$ & Trans : cis & Trans ee $/ \%^{c}$ \\
\hline 1 & $\mathrm{CH}_{2} \mathrm{Cl}_{2}$ & $54[99]$ & $94: 6$ & 51 \\
2 & $\mathrm{MeCN}^{\mathrm{c}}$ & $72[99]$ & $96: 4$ & 56 \\
$3^{\mathrm{d}}$ & $\mathrm{MeCN} / \mathrm{H}_{2} \mathrm{O}(\mathrm{v} / \mathrm{v} 9: 1)$ & $43[51]$ & $77: 23$ & 47 \\
4 & $t-\mathrm{BuOH}$ & $30[99]$ & $77: 23$ & 71 \\
\hline
\end{tabular}

${ }^{a}$ Reactions were carried out in the presence of $\mathrm{K}_{2} \mathrm{CO}_{3}$ (3.0 equiv.) at room temperature for 4 days using 1.0 equiv. 6a, 3.0 equiv. benzyl bromide and 1.0 equiv. 1. ${ }^{\mathrm{b}}$ Isolated yields. In square brackets, yields based on consumed amounts of benzaldehyde 6a. ${ }^{\mathrm{c}}$ Determined by HPLC [Chiralcel OD, i-PrOH-hexane (1:100)]. The absolute configuration was assigned [S,S] by comparison of the sign (-) of specific rotation with the literature data. ${ }^{\mathrm{d}}$ For 1 week.

In order to see possibility of the catalytic process of this one-pot epoxidation, the reactions of 6a,b with benzyl bromide in the presence of varied quantities of chiral sulfide 1 were examined. The results are shown in Table 10. Obviously, degrees of the diastereo- and enantioselectivities in each reaction were not so markedly decreased by reducing the amounts of $\mathbf{1}$ added, while the reaction became slow (runs 1-4 and 5-8). The electron-withdrawing p-nitro substituent of benzaldehyde obviously accelerated the reaction and good yield of epoxide $\mathbf{8 b}$ was obtained. Although sub-stoichiometric amounts of sulfide $\mathbf{1}$ are necessary to obtain higher yields and stereoselectivities, a merit of this epoxidation is that after the reaction, chiral sulfide $\mathbf{1}$ was recovered optically pure in good yield and could be reused. 
Table 10. Dependence on stoichiometry of chiral sulfide $\mathbf{1}$ in one-pot epoxidation of $\mathbf{6 a}, \mathbf{b}$ to afford 8a,b

\begin{tabular}{llllccc}
\hline Run & $\mathrm{R}^{1}\left(\mathrm{R}^{2}=\mathrm{Ph}\right)$ & $\mathrm{n}($ equiv.) $\mathbf{1}$ & Time $(\mathrm{d})$ & Yield $(\%)$ & Trans : cis $^{\mathrm{c}}$ & ${\text { Trans ee }(\%)^{\mathrm{c}}}$ \\
\hline 1 & $\mathrm{Ph}$ & 1.0 & 4 & $72[99]$ & $96: 4$ & 56 \\
2 & & 0.5 & 4 & $63[96]$ & $94: 6$ & 55 \\
3 & & 0.2 & 4 & $36[45]$ & $94: 6$ & 46 \\
4 & & 0.1 & 4 & $35[41]$ & $91: 9$ & 44 \\
5 & $p-\mathrm{NO}_{2} \mathrm{C}_{6} \mathrm{H}_{4}$ & 1.0 & 1 & 99 & $96: 4$ & 57 \\
6 & & 0.5 & 1.5 & 99 & $98: 2$ & 52 \\
7 & & 0.2 & 3.5 & 99 & $90: 10$ & 48 \\
8 & & 0.1 & 6 & 99 & $88: 12$ & 48 \\
\hline
\end{tabular}

${ }^{a}$ Reactions were carried out in the presence of $\mathrm{K}_{2} \mathrm{CO}_{3}$ (3.0 equiv.) in $\mathrm{MeCN}$ at room temperature using 1.0 equiv. 6a,b, 3.0 equiv. benzyl bromide and $n$ equiv. 1. ${ }^{b}$ Isolated yields. In square brackets, yields based on consumed amounts of benzaldehyde 6a. ${ }^{\mathrm{c}}$ Determined by HPLC [Chiralcel OD, i-PrOH-hexane (1:50-100)]. The absolute configuration was assigned [S,S] by comparison of the sign (-) of specific rotation with the literature data.

Finally, the reactions of variously substituted aromatic aldehydes $\mathbf{6}$ and alkyl bromides were carried out in the presence of an equimolar amount $(n=1.0)$ of 1 under the optimized reaction conditions. The epoxides 8 were obtained in fairly good yields and stereoselectivities (Table 11). From the viewpoint of enantioselectivity, it is suggested that recommended are the reactions with benzyl bromide in $t$-BuOH for syntheses of trans-epoxides 8a-c,e and $\mathbf{8 g}$ (runs 12-14, 16, and 17), whilst the reaction with $p$-methylbenzyl bromide in $\mathrm{MeCN}$ (run 10) is preferable to those of runs 4 and 15 for synthesis of trans-2-phenyl-3-p-tolyl epoxide 8d. In this one-pot method, the chiral sulfide 1 used was again virtually quantitatively recovered enantiomerically pure after the reaction and could be used repeatedly. 
Table 11. One pot epoxidation of $\mathbf{6}$ bearing a variety of substituents with benzyl bromide to afford $8{ }^{\text {a }}$

\begin{tabular}{|c|c|c|c|c|c|c|c|c|}
\hline \multirow{2}{*}{\multicolumn{2}{|c|}{$\frac{\text { Run } \mathrm{R}^{1}}{<\mathrm{In} \mathrm{MeCN}>}$}} & \multirow{2}{*}{$\mathrm{R}^{2}$} & \multirow[t]{2}{*}{ Time (d) } & \multirow[t]{2}{*}{ Epoxide } & \multirow[t]{2}{*}{ Yield $(\%)^{b}$} & \multirow[t]{2}{*}{ Trans : cis $^{\mathrm{c}}$} & \multicolumn{2}{|c|}{ Trans ee $(\%)^{c}$} \\
\hline & & & & & & & & \\
\hline 1 & $\mathrm{Ph}$ & $\mathrm{Ph}$ & 4 & $8 a$ & 72 [99] & $94: 6$ & 56 & {$[\mathrm{~S}, \mathrm{~S}]$} \\
\hline 2 & $p-\mathrm{NO}_{2} \mathrm{C}_{6} \mathrm{H}_{4}$ & $\mathrm{Ph}$ & 1 & $8 \mathbf{b}$ & 99 & $95: 5$ & 57 & {$[\mathrm{~S}, \mathrm{~S}]$} \\
\hline 3 & $p-\mathrm{ClC}_{6} \mathrm{H}_{4}$ & $\mathrm{Ph}$ & 2 & $8 c$ & 99 & $90: 10$ & 46 & {$[\mathrm{~S}, \mathrm{~S}]$} \\
\hline 4 & $p$-Tol & $\mathrm{Ph}$ & 4 & 8d & $84[90]$ & $81: 19$ & 75 & {$[\mathrm{~S}, \mathrm{~S}]$} \\
\hline 5 & $p-\mathrm{MeOC}_{6} \mathrm{H}_{4}$ & $\mathrm{Ph}$ & 4 & $8 e$ & 33 [89] & $83: 17$ & 61 & {$[\mathrm{~S}, \mathrm{~S}]$} \\
\hline 6 & $\beta$-Styryl & $\mathrm{Ph}$ & 4 & $8 g$ & 68 & $>99:<1$ & 40 & {$[\mathrm{~S}, \mathrm{~S}]$} \\
\hline 7 & $o-\mathrm{HOC}_{6} \mathrm{H}_{4}$ & $\mathrm{Ph}$ & 4 & $8 k^{d}$ & 57 [99] & $97: 3$ & 47 & {$[\mathrm{~S}, \mathrm{~S}]$} \\
\hline 8 & 2-Pyridyl & $\mathrm{Ph}$ & 1 & $8 \mathbf{j}$ & 99 & $>99:<1$ & 45 & {$[\mathrm{~S}, \mathrm{~S}]$} \\
\hline 9 & $\mathrm{Ph}$ & $p-\mathrm{NO}_{2} \mathrm{C}_{6} \mathrm{H}_{4}$ & 4 & $8 \mathbf{b}$ & 73 [99] & $72: 28$ & 22 & {$[\mathrm{~S}, \mathrm{~S}]$} \\
\hline 10 & $\mathrm{Ph}$ & $p$-Tol & 4 & 8d & 58 [69] & $80: 20$ & 91 & {$[\mathrm{~S}, \mathrm{~S}]$} \\
\hline 11 & $\mathrm{Ph}$ & $\beta$-Styryl & 3 & $8 \mathrm{~g}$ & 66 & $79: 21$ & 20 & {$[\mathrm{~S}, \mathrm{~S}]$} \\
\hline & $=\operatorname{In} t-\mathrm{BuOH}>$ & & & & & & & \\
\hline 12 & $\mathrm{Ph}$ & $\mathrm{Ph}$ & 4 & $8 a$ & 24 [99] & $77: 23$ & 71 & {$[\mathrm{~S}, \mathrm{~S}]$} \\
\hline 13 & $p-\mathrm{NO}_{2} \mathrm{C}_{6} \mathrm{H}_{4}$ & $\mathrm{Ph}$ & 1 & $8 \mathbf{b}$ & 99 & $76: 24$ & 76 & {$[\mathrm{~S}, \mathrm{~S}]$} \\
\hline 14 & $p-\mathrm{ClC}_{6} \mathrm{H}_{4}$ & $\mathrm{Ph}$ & 3 & $8 c$ & 99 & $79: 21$ & 75 & {$[\mathrm{~S}, \mathrm{~S}]$} \\
\hline 15 & $p$-Tol & $\mathrm{Ph}$ & 4 & 8d & 51 [99] & $76: 24$ & 66 & {$[\mathrm{~S}, \mathrm{~S}]$} \\
\hline 16 & $p-\mathrm{MeOC}_{6} \mathrm{H}_{4}$ & $\mathrm{Ph}$ & 4 & $8 e$ & $47[85]$ & $77: 23$ & 65 & {$[\mathrm{~S}, \mathrm{~S}]$} \\
\hline 17 & $\beta$-Styryl & $\mathrm{Ph}$ & 3 & $8 g$ & 80 & $90: 10$ & 78 & {$[\mathrm{~S}, \mathrm{~S}]$} \\
\hline 18 & $\mathrm{Ph}$ & $p-\mathrm{NO}_{2} \mathrm{C}_{6} \mathrm{H}_{4}$ & 4 & $8 \mathbf{b}$ & $36[90]$ & $73: 27$ & 22 & {$[\mathrm{~S}, \mathrm{~S}]$} \\
\hline
\end{tabular}

${ }^{a}$ Reactions were carried out at room temperature $\left(22-25{ }^{\circ} \mathrm{C}\right)$ using 1.0 equiv. 6 and 3.0 equiv. alkyl bromide in the presence of $\mathrm{K}_{2} \mathrm{CO}_{3}$ (3.0 equiv.) as a base. ${ }^{\mathrm{b}}$ Isolated yields. In square brackets, yields based on consumed amounts of aldehyde 6. ${ }^{\mathrm{c}}$ Determined by HPLC [Chiralcel OD or AD, $i-\mathrm{PrOH}-$ hexane (1:20-200) or EtOH-hexane (1:20-50)]. The absolute configuration of trans isomers was assigned $[S, S]$ by comparison of the sign (-) of specific rotation with the literature data or by assumption. ${ }^{\mathrm{d}}$ ortho-O-benzylated epoxide was obtained. 


\section{Rationale for enantio- and diastereoselectivities}

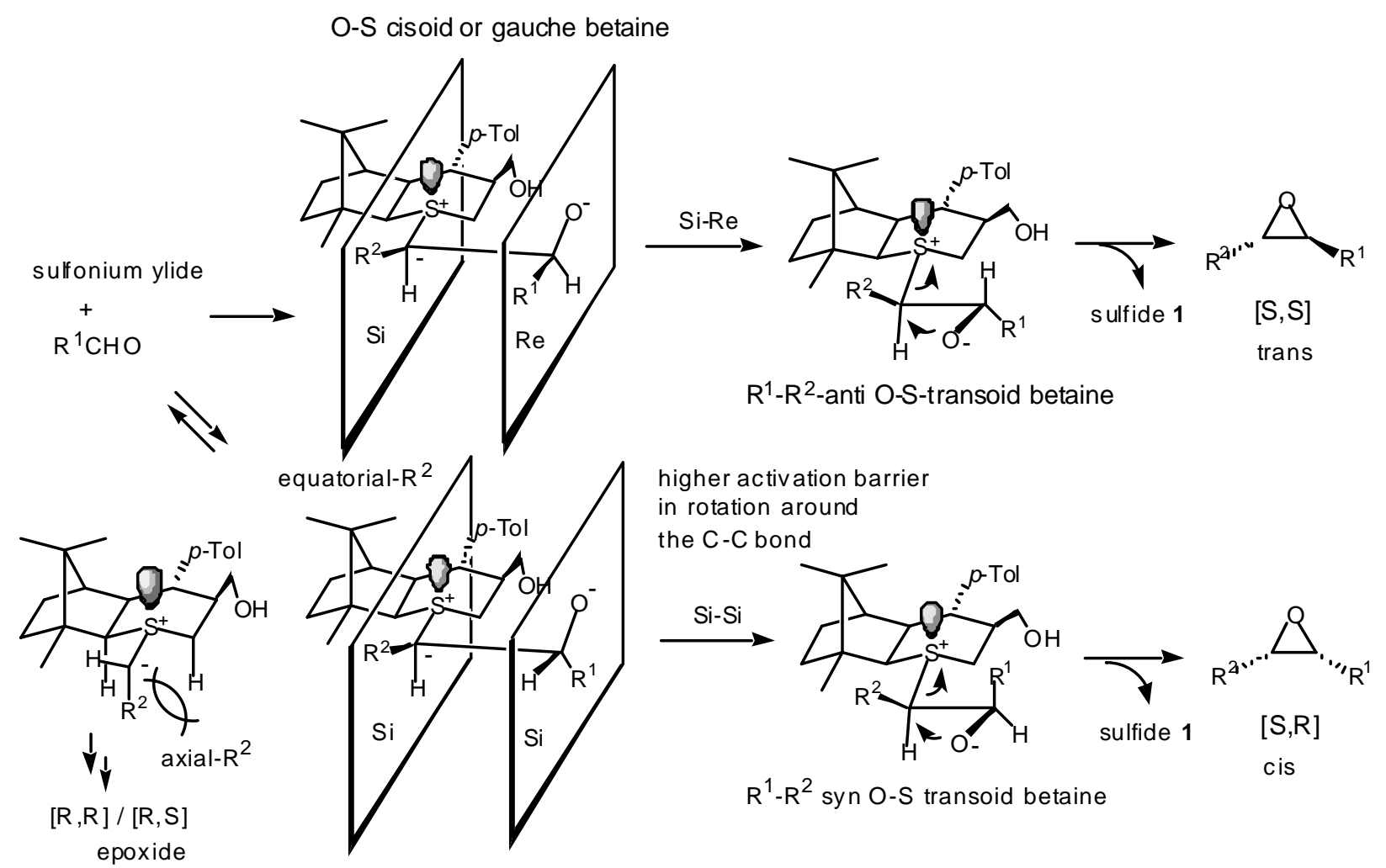

\section{Scheme 5}

Recently, mechanisms of carbonyl epoxidation with sulfonium ylide based on computational studies have been proposed by Aggarwal et al. ${ }^{14 a}$ and Koskinen et al.. ${ }^{14 b}$ On the basis of their proposal, the predominant formation of $(S, S)$-trans-stilbene oxides observed in the epoxidation with the sulfonium ylide derived from chiral sulfide $\mathbf{1}$ can essentially be explained as illustrated in Scheme 5. (i) The sulfonium ylide adopts two dominant conformations in which the filled orbital on the ylide carbon is orthogonal to the sulfur lone pair. (ii) The conformation having the $\mathrm{R}^{2}$ group in an equatorial position is favored over the other one with an axial $\mathrm{R}^{2}$ group due to steric repulsion between the $\mathrm{R}^{2}$ group and the diaxial protons in the thiane ring. (iii) The aldehyde attacks the ylide carbon preferably from the less hindered Si face with an arrangement of the aldehyde as to be attacked from the Re face or the Si face in a manner of cisoid ([2+2]) or gauche addition with coulombic interaction to form the cisoid betaines. The former (Si-Re) cisoid betaine forms the anti-transoid betaine via the rotation around the $\mathrm{C}-\mathrm{C}$ bond. The internal nucleophilic substitution with trans elimination of sulfide 1 leads to a stereoselective formation of $(S, S)$-trans-epoxides, while the syn-transoid betaine formed from the syn-cisoid betaine (Si$\mathrm{Si})$ leads to $(S, R)$-cis-epoxide. The higher becomes the activation barrier in the tortional rotation step from the syn-cisoid ( $\mathrm{Si}-\mathrm{Si}$ ) to the syn-transoid betaine, the greater increases the degree of reversibility to the starting materials; thus, it leads to high trans selectivity. The distribution of 
these key species involved in the pathways is significantly influenced by the factors such as substituents (electronic property, steric hindrance) and solvents (charge solvation). ${ }^{\dagger}$ Although the sense of asymmetric induction and diastereoselectivity could be thus explained, the observed enantioselectivity was not so high than that expected. This is ascribable most likely to partial release of controlling the ylide conformation as the factor (ii), ${ }^{1 \mathrm{c}}$ nevertheless, much better enantioselectivity was observed in the imino Corey-Chaykovsky aziridination by the use of the same ylides derived from sulfide $\mathbf{1}^{12 \mathrm{a}}$ It is also noteworthy that a simple, relatively less congested $\mathrm{C}_{2}$-symmetric sulfide (2,5-dimethylthiolane, 2,5-diethylthiolane) is an efficient catalyst for the epoxidation via the ylide route. ${ }^{6}$

\section{Conclusions}

The present study demonstrates diastereo- and enantioselective synthesis of optically active epoxides via the Corey-Chaykovsky reaction. Although the stereoselectivities observed were moderate to good, the methods are promising because of the easy and simple but efficient preparation of the chiral sulfide with good crystallinity and the feasible introduction of a variety of substituents to the tetrahydrothiopyran ring to tune up the stereoselectivities by further manipulation. Moreover, the chiral sulfide can be recovered optically pure and essentially quantitatively and reused.

\section{Experimental Section}

General Procedures. Melting points are uncorrected. Analytical TLC was carried out on Merk silica gel 60 F254 plates. Visualization was performed with UV light, p-anisaldehyde/sulfuric acid, phosphomolybdic acid, and/or $\mathrm{KMnO}_{4}$. Column chromatography was conducted on silica gel (100-200 mesh) or on alumina (100-200 mesh). IR spectra were recorded on a Hitachi Model 270-30 instrument. ${ }^{1} \mathrm{H} \mathrm{NMR}$ and ${ }^{13} \mathrm{C}$ NMR spectra were measured at 100, 270 and/or $500 \mathrm{MHz}$ for ${ }^{1} \mathrm{H}$, and at 25, 67.8 and/or $125.65 \mathrm{MHz}$ for ${ }^{13} \mathrm{C}$ using JEOL JNM-FX 100, JEOL JNM-EX 270 and JEOL JNM-LA 500 spectrometers. Chemical shifts from tetramethylsilane (TMS) as an internal standard are given in ppm and coupling constants, $J$, in Hz. Mass spectra (EI or FAB) were obtained with a Hitachi Model M-80B double focusing mass spectrometer with a data processing system M-0101. Elemental combustion microanalyses were performed on a PerkinElmer $2400 \mathrm{CHNS} / \mathrm{O}$ Elemental Analyzer. Optical rotations were recorded on a Nippon Bunko Model DIP-370 digital Polarimeter and are reported in units of $10^{-1} \mathrm{degcm}^{2} \mathrm{~g}^{-1}$. Enantiomeric excesses and ratios of trans and cis isomers were determined by HPLC measurement using

\footnotetext{
$\dagger$ Aggarwal et al. proposed a general rationalization for the origins of diastereo (trans vs. cis)- and enantioselectivities including their dependence on substituents and solvents in the sulfur ylide-carbonyl epoxidation. For further discussion, see literature ${ }^{10 a, 14 a}$.
} 
chiralcel OD, AD and AS columns (0.5-20\% i-PrOH-hexane, 0.3-5 \% EtOH-hexane) on a Millipore-Waters 996 instrument or Shiseido Model S-MicroChrom instrument.

Preparation of chiral sulfide (1). [(1R, 2R, 5S, 6R, 7R, 8R)-(1,11,11-Trimethyl-6-p-tolyl-3-thiatricyclo[6.2.1. $\left.0^{2,7}\right]$ undec-5-yl)-methanol]. A mixture of $d$-camphor (30 mmol, $\left.4.57 \mathrm{~g}\right), p$ tolualdehyde ( $36 \mathrm{mmol}, 4.33 \mathrm{~g}$ ) and potassium t-butoxide $(39 \mathrm{mmol}, 4.38 \mathrm{~g})$ was heated in $t$ butyl alcohol $(37 \mathrm{~mL})$ for $5 \mathrm{~h}$ under reflux. The reaction mixture was neutralized with aq. $\mathrm{HCl}$, extracted with ethyl acetate $(20 \mathrm{~mL} \times 3)$ and the combined extracts was washed with saturated aq. $\mathrm{NaCl}$ solution and dried over $\mathrm{MgSO}_{4}$. Evaporation of the solvent and column chromatography of the residue on silica gel using EtOAc-hexane (1:5) as an eluent to give 3-(ptolylmethylene)camphor $2(6.25 \mathrm{~g}, 82 \%$ yield $)$ as a colorless solid after crystallization from hexane, mp 97.2-98.2 ${ }^{\circ} \mathrm{C}$; IR ( $\mathrm{KBr}$ disk, $\mathrm{cm}^{-1}$ ) 2916, 1704, 1628, 1506, 1436, 1368, 1320, 1250, 1144, 1102, 1056, 1012, 958, 918, 808 and 744; ${ }^{1} \mathrm{H}-\mathrm{NMR}\left(100 \mathrm{MHz}, \mathrm{CDCl}_{3}\right) \delta 0.80(3 \mathrm{H}, \mathrm{s}), 0.99$ $(3 \mathrm{H}, \mathrm{s}), 1.02(3 \mathrm{H}, \mathrm{s}), 1.48-1.60(2 \mathrm{H}, \mathrm{m}), 1.77(1 \mathrm{H}, \mathrm{dt}, J 3.1,12.2), 2.14-2.20(1 \mathrm{H}, \mathrm{m}), 2.36(3 \mathrm{H}$, s), $3.10\left(1 \mathrm{H}, \mathrm{d}, J\right.$ 4.0), $7.19\left(2 \mathrm{H}, \mathrm{d}, J\right.$ 7.9), $7.21(1 \mathrm{H}, \mathrm{s}), 7.38(2 \mathrm{H}, \mathrm{d}, J 7.9) ;{ }^{13} \mathrm{C}-\mathrm{NMR}(25 \mathrm{MHz}$, $\mathrm{CDCl}_{3}$, DEPT) $\delta 9.23\left(\mathrm{CH}_{3}\right), 18.27\left(\mathrm{CH}_{3}\right), 20.16\left(\mathrm{CH}_{3}\right), 21.30\left(\mathrm{CH}_{3}\right), 25.85\left(\mathrm{CH}_{2}\right), 30.67\left(\mathrm{CH}_{2}\right)$, $46.63(\mathrm{C}), 49.15(\mathrm{CH}), 56.97(\mathrm{C}), 127.48(\mathrm{CH}), 129.31$ (CHx2), 129.69 (CHx2), $132.73(\mathrm{C})$, 138.84 (C), 141.16 (C), 208.17 (C); MS (FAB) m/z 255 (M+H', 100), 254 (40), 105 (14); HRMS (FAB) Calcd for $\mathrm{C}_{18} \mathrm{H}_{22} \mathrm{OH}$ : $\mathrm{M}+\mathrm{H}$ 255.1749. Found, 255.1746. Anal. Calcd for $\mathrm{C}_{18} \mathrm{H}_{22} \mathrm{O}: \mathrm{C}$, 84.99; H, 8.72. Found: C, 85.03; H, 8.96.

A mixture of 3-( $p$-tolylmethylene)camphor $2(10 \mathrm{mmol}, 2.54 \mathrm{~g})$ and Lawesson's reagent (6 $\mathrm{mmol}, 2.42 \mathrm{~g}$ ) was heated in benzene under reflux for $2 \mathrm{~h}$. Evaporation of the solvent and column chromatography of the residue on silica gel [benzene-hexane (1:4)] gave 3-(ptolylmethylene)camphorthione 3 ( $2.14 \mathrm{~g}, 79 \%$ yield) as blue needles after recrystallization from hexane, mp 146-147 ${ }^{\circ} \mathrm{C}$; IR (KBr disk, $\mathrm{cm}^{-1}$ ) 2962, 2920, 1626, 1606, 1312, 1278, 1261, 1240, 1062 and 912; ${ }^{1} \mathrm{H}-\mathrm{NMR}\left(100 \mathrm{MHz}, \mathrm{CDCl}_{3}\right) \delta 0.75(3 \mathrm{H}, \mathrm{s}), 1.05(3 \mathrm{H}, \mathrm{s}), 1.20(3 \mathrm{H}, \mathrm{s}), 1.24-2.33$ $(4 \mathrm{H}, \mathrm{m}), 2.36(3 \mathrm{H}, \mathrm{s}), 3.22(1 \mathrm{H}, \mathrm{d}, J 4.0), 7.17(2 \mathrm{H}, \mathrm{d}, J 8.0), 7.43(2 \mathrm{H}, \mathrm{d}, J 8.0), 7.56(1 \mathrm{H}, \mathrm{s})$; ${ }^{13} \mathrm{C}-\mathrm{NMR}\left(25 \mathrm{MHz}, \mathrm{CDCl} 3\right.$, DEPT) $\delta 13.50\left(\mathrm{CH}_{3}\right), 19.02\left(\mathrm{CH}_{3}\right), 20.25\left(\mathrm{CH}_{3}\right), 21.55\left(\mathrm{CH}_{3}\right)$, $25.71\left(\mathrm{CH}_{2}\right), 34.17\left(\mathrm{CH}_{2}\right), 49.19(\mathrm{C}), 50.89(\mathrm{CH}), 67.75(\mathrm{C}), 129.10(\mathrm{CH}), 129.51(\mathrm{CHx} 2)$, 130.27 (CHx2), 133.47 (C), 139.21 (C), 149.37 (C), 252.70 (C); MS (EI, 70eV) m/z 270 (M, 69), $269\left(\mathrm{M}^{+}-1,66\right), 255\left(\mathrm{M}^{+}-\mathrm{CH}_{3}, 100\right)$; HRMS (FAB) Calcd for $\mathrm{C}_{18} \mathrm{H}_{22} \mathrm{SH}: \mathrm{M}+\mathrm{H} 271.1520$. Found: 271.1522. Anal. Calcd for $\mathrm{C}_{18} \mathrm{H}_{22} \mathrm{~S}$ : C, 79.94; H, 8.20. Found: C, 79.82; H, 8.44.

To a solution of methyl acrylate $(3.0 \mathrm{mmol}, 0.296 \mathrm{~mL})$ in dichloromethane $(29 \mathrm{~mL})$ was added a $1.0 \mathrm{M}$ titanium tetrachloride dichloromethane solution $(0.3 \mathrm{~mL})$ at $\mathrm{rt}$ with stirring for 1 h. 3-(p-Tolylmethylene)camphorthione 3 (3.0-3.6 mmol, 0.81-0.97 g) was then added to the solution with stirring at rt. After 10 min the reaction was quenched with water. The mixture was extracted with dichloromethane ( $15 \mathrm{~mL}$ x 2), washed with saturated aq. $\mathrm{NaCl}$ solution and dried over $\mathrm{MgSO}_{4}$. Evaporation of the solvent and short column chromatography of the residue [83:17 ratio of trans and cis isomers ( $\left.\left.{ }^{1} \mathrm{H} \mathrm{NMR}\right)\right]$ on silica gel using EtOAc-hexane (1:3) as an eluent to give a mixture of trans- and cis-isomers 4 (1.06 g, $99 \%$ yield), which was used for the next step (LAH reduction) without separation of the isomers. Alternatively, thin layer chromatography or 
column chromatography [silica gel, EtOAc-hexane (1:10)] of the mixture afforded the major trans-cycloadduct $4(0.87 \mathrm{~g})$ as a yellowish oil. $[\alpha]_{\mathrm{D}}+171\left(\mathrm{CHCl}_{3}, \mathrm{c} 0.23\right)$; IR (neat, $\left.\mathrm{cm}^{-1}\right) 2952$, 2870, 1741, 1621, 1512, 1436, 1170, 1021, 910, 821, 788 and 734; ${ }^{1} \mathrm{H}-\mathrm{NMR}\left(100 \mathrm{MHz}, \mathrm{CDCl}_{3}\right)$ $\delta 0.72(3 \mathrm{H}, \mathrm{s}), 0.85(3 \mathrm{H}, \mathrm{s}), 0.75-2.30(4 \mathrm{H}, \mathrm{m}), 0.96(3 \mathrm{H}, \mathrm{s}), 2.05(1 \mathrm{H}, \mathrm{d}, J 2.8), 2.30(3 \mathrm{H}, \mathrm{s})$, $2.87(1 \mathrm{H}, \mathrm{dt}, J 4.5,4.5), 3.08(2 \mathrm{H}, \mathrm{d}, J 4.5), 3.63(3 \mathrm{H}, \mathrm{s}), 3.98(1 \mathrm{H}, \mathrm{d}, J 4.5), 7.01(2 \mathrm{H}, \mathrm{d}, J$ 7.9), $7.09\left(2 \mathrm{H}, \mathrm{d}, J\right.$ 7.9); ${ }^{13} \mathrm{C}-\mathrm{NMR}\left(25 \mathrm{MHz}, \mathrm{CDCl}_{3}\right) \delta 11.01\left(\mathrm{CH}_{3}\right), 19.15\left(\mathrm{CH}_{3}\right), 19.50\left(\mathrm{CH}_{3}\right), 21.01$ $\left(\mathrm{CH}_{3}\right), 25.29\left(\mathrm{CH}_{2}\right), 26.46\left(\mathrm{CH}_{2}\right), 33.39\left(\mathrm{CH}_{2}\right), 42.84(\mathrm{CH}), 46.15(\mathrm{CH}), 51.81\left(\mathrm{CH}_{3}\right), 55.90$ (CH), 56.10 (C), 57.46 (C), 126.62 (CHx2), 129.01 (CHx2), 132.96 (C), 135.39 (C), 136.27 (C), 139.58 (C), 172.82 (C); MS (EI, $70 \mathrm{eV}) \mathrm{m} / \mathrm{z} 356\left(\mathrm{M}^{+}, 100\right)$. Cis-cycloadduct 4 (0.17 g) was also separated pure as yellowish needles after crystallization from dichloromethane-hexane, $\mathrm{mp} 58-59^{\circ} \mathrm{C}$, $[\alpha]_{\mathrm{D}}+201\left(\mathrm{CHCl}_{3}, \mathrm{c} 3.0\right)$; IR (KBr disk, $\left.\mathrm{cm}^{-1}\right)$ 2952, 2872, 1738, 1620, 1512, 1434, 1248, 1170, 1024 and 808; ${ }^{1} \mathrm{H}-\mathrm{NMR}\left(100 \mathrm{MHz}, \mathrm{CDCl}_{3}\right) \delta 0.75(3 \mathrm{H}, \mathrm{s}), 0.88(3 \mathrm{H}, \mathrm{s}), 0.59-2.30(4 \mathrm{H}, \mathrm{m}), 1.00$ $(3 \mathrm{H}, \mathrm{s}), 2.10(1 \mathrm{H}, \mathrm{d}, 3.3), 2.28(3 \mathrm{H}, \mathrm{s}), 2.70-3.20(3 \mathrm{H}, \mathrm{m}), 3.51(3 \mathrm{H}, \mathrm{s}), 3.94(1 \mathrm{H}, \mathrm{d}, 3.8), 6.86$ $(2 \mathrm{H}, \mathrm{d}, 8.6) 7.01(2 \mathrm{H}, \mathrm{d}, 8.6) ;{ }^{13} \mathrm{C}-\mathrm{NMR}\left(25 \mathrm{MHz}, \mathrm{CDCl}_{3}\right) \delta 10.87\left(\mathrm{CH}_{3}\right), 19.25\left(\mathrm{CH}_{3}\right), 19.45$ $\left(\mathrm{CH}_{3}\right), 21.05\left(\mathrm{CH}_{3}\right), 22.13\left(\mathrm{CH}_{2}\right), 26.81\left(\mathrm{CH}_{2}\right), 33.29\left(\mathrm{CH}_{2}\right), 43.38(\mathrm{CH}), 45.18(\mathrm{CH}), 51.37$ $\left(\mathrm{CH}_{3}\right), 56.00(\mathrm{C}), 56.93(\mathrm{CH}), 57.46(\mathrm{C}), 128.72$ (CHx2), 129.15 (CHx2), $133.15(\mathrm{C}), 135.49$ (C), 136.71 (C), 136.95 (C), 172.97 (C); MS (EI, 70 eV) m/z $356\left(\mathrm{M}^{+}, 100\right)$.

To a suspension of lithium aluminum hydride $(2.25 \mathrm{mmol}, 0.085 \mathrm{~g})$ in dry THF $(20 \mathrm{~mL})$ was added a THF solution $(15 \mathrm{~mL})$ of trans-4 $(3.0 \mathrm{mmol}, 1.07 \mathrm{~g})$ at $0{ }^{\circ} \mathrm{C}$. The reaction mixture was warmed to $\mathrm{rt}$ with stirring. After $10 \mathrm{~min}$, the reaction mixture was treated with dilute aq $\mathrm{HCl}$ on cooling, extracted with EtOAc $\left(15 \mathrm{~mL}\right.$ x 3) and dried over $\mathrm{MgSO}_{4}$. Evaporation and column chromatography of the residue on silica gel [EtOAc-hexane (1: 9)] afforded alcohol 5 (82\% yield) as colorless needles after recrystallization from EtOAc-hexane, mp 144.1-144.6 ${ }^{\circ} \mathrm{C},[\alpha]_{\mathrm{D}}$ $+112\left(\mathrm{CHCl}_{3}, \mathrm{c} 2.96\right)$; ${ }^{1} \mathrm{H}-\mathrm{NMR}\left(500 \mathrm{MHz}, \mathrm{CDCl}_{3}\right) \delta 0.73(3 \mathrm{H}, \mathrm{s}), 0.84(3 \mathrm{H}, \mathrm{s}), 0.93-1.01(1 \mathrm{H}$, m), $0.99(3 \mathrm{H}, \mathrm{s}), 1.32-1.38(1 \mathrm{H}, \mathrm{m}), 1.49(1 \mathrm{H}, \mathrm{br} \mathrm{s}), 1.53-1.67(2 \mathrm{H}, \mathrm{m}), 2.01(1 \mathrm{H}, \mathrm{d}, J 3.2), 2.01-$ $2.08(1 \mathrm{H}, \mathrm{m}), 2.32(3 \mathrm{H}, \mathrm{s}), 2.77(1 \mathrm{H}, \mathrm{dd}, J 5.4,12.9), 3.12(1 \mathrm{H}, \mathrm{dd}, J 2.7,12.9), 3.33(1 \mathrm{H}, \mathrm{d}, J$ 3.4), 3.64 (1H, dd, J 5.6, 10.5), $3.74(1 \mathrm{H}, \mathrm{dd}, J 8.3,10.5), 6.97-7.13(4 \mathrm{H}, \mathrm{m}) ;{ }^{13} \mathrm{C}-\mathrm{NMR}(125.65$ $\left.\mathrm{MHz}, \mathrm{CDCl}_{3}\right) \delta 10.97\left(\mathrm{CH}_{3}\right), 19.48\left(\mathrm{CH}_{3}\right), 19.50\left(\mathrm{CH}_{3}\right), 20.96\left(\mathrm{CH}_{3}\right), 24.83\left(\mathrm{CH}_{2}\right), 26.53\left(\mathrm{CH}_{2}\right)$, $33.45\left(\mathrm{CH}_{2}\right), 42.41(\mathrm{CH}), 43.14(\mathrm{CH}), 56.12(\mathrm{CH}), 56.17(\mathrm{C}), 57.26(\mathrm{C}), 64.37\left(\mathrm{CH}_{2}\right), 128.46$ (CHx2), 128.91 (CHx2), 132.55 (C), 135.40 (C), 135.98 (C), 141.04(C); MS (EI, 70 eV) m/z 328 $\left(\mathrm{M}^{+}, 72\right), 300\left(\mathrm{M}^{+}-\mathrm{CH}_{2} \mathrm{CH}_{2}, 100\right)$; HRMS Calcd for $\mathrm{C}_{21} \mathrm{H}_{28} \mathrm{OS}$ : M 328.1862. Found: 328.1858. Anal. Calcd for $\mathrm{C}_{21} \mathrm{H}_{28} \mathrm{OS}$ : C, 76.78; H, 8.59. Found: C, 76.65; H, 8.76.

A mixture of alcohol 5 (3.0 mmol, $0.986 \mathrm{~g}), 5 \% \mathrm{Pd} / \mathrm{C}(0.0986 \mathrm{~g})$ and camphorsulfonic acid $(0.3 \mathrm{mmol}, 0.07 \mathrm{~g})$ in ethanol $(5 \mathrm{~mL})$ was vigorously stirred overnight under a hydrogen atmosphere at rt. The mixture was neutralized with aq. $\mathrm{NaHCO}_{3}$ and extracted with dichloromethane. The combined organic layer was washed with saturated aq. $\mathrm{NaCl}$ and dried over $\mathrm{MgSO}_{4}$. Evaporation and column chromatography of the residue on silica gel [benzenehexane (1: 3)] afforded sulfide 1 (82\% yield). Recrystallization from EtOAc-hexane gave optically pure chiral sulfide 1 as colorless needles mp 128.6-129.6 ${ }^{\circ} \mathrm{C},[\alpha]_{\mathrm{D}}+21\left(\mathrm{CHCl}_{3}, \mathrm{c} 1.97\right)$; IR (KBr disk, $\mathrm{cm}^{-1}$ ) 3276, 2872, 1428, 1388, 1298 and 998; ${ }^{1} \mathrm{H}-\mathrm{NMR}\left(500 \mathrm{MHz}, \mathrm{CDCl}_{3}\right) \delta 0.75$ $(3 \mathrm{H}, \mathrm{s}), 0.93-0.99(1 \mathrm{H}, \mathrm{m}), 0.97(3 \mathrm{H}, \mathrm{s}), 1.27-1.31(2 \mathrm{H}, \mathrm{m}), 1.45(3 \mathrm{H}, \mathrm{s}), 1.56-1.67(2 \mathrm{H}, \mathrm{m})$, 
1.90-1.97 (1H, m), $1.92(1 \mathrm{H}, \mathrm{dd}, 9.2,13.4), 2.33(3 \mathrm{H}, \mathrm{s}), 2.77(1 \mathrm{H}, \mathrm{dd}, 10.7,13.4), 2.80$ (1H, dd, 7.6, 14.0), $2.92(1 \mathrm{H}, \mathrm{dd}, 1.5,14.0), 3.35(1 \mathrm{H}, \mathrm{dd}, 7.6,10.4), 3.38(1 \mathrm{H}, \mathrm{dd}, 10.4,10.4), 3.40(1 \mathrm{H}$, $\mathrm{d}, 9.2), 7.06(2 \mathrm{H}, \mathrm{d}, 7.9), 7.11(2 \mathrm{H}, \mathrm{d}, 7.9) ;{ }^{1} \mathrm{H}-\mathrm{NMR}(500 \mathrm{MHz}, \mathrm{C} 6 \mathrm{D} 6) \delta 0.51-0.57$ (1H, m), $0.66(3 \mathrm{H}, \mathrm{s}), 0.83(1 \mathrm{H}, \mathrm{dd}, 8.1,9.2), 1.05(3 \mathrm{H}, \mathrm{s}), 1.16(1 \mathrm{H}, \mathrm{dd}, 8.1,9.5), 1.36(1 \mathrm{H}, \mathrm{d}, 3.1), 1.47-$ $1.50(1 \mathrm{H}, \mathrm{m}), 1.56(3 \mathrm{H}, \mathrm{s}), 1.66(1 \mathrm{H}, \mathrm{dd}, 9.5,12.8), 1.71-1.77(1 \mathrm{H}, \mathrm{m}), 2.16(3 \mathrm{H}, \mathrm{s}), 2.63(1 \mathrm{H}$, $\mathrm{dd}, 7.3,14.0), 2.77(1 \mathrm{H}, \mathrm{dd}, 10.7,12.8), 2.95$ (1H, ddd, 0.3, 1.5, 14.0), 3.17-3.22 (2H, m), 3.23 $(1 \mathrm{H}, \mathrm{d}, 9.5), 6.94(2 \mathrm{H}, \mathrm{d}, 7.9), 6.99(2 \mathrm{H}, \mathrm{d}, 7.9)\left(\mathrm{OH}\right.$ peak was not detected); ${ }^{13} \mathrm{C}-\mathrm{NMR}(125$ $\left.\mathrm{MHz}, \mathrm{CDCl}_{3}\right) \delta 13.27\left(\mathrm{CH}_{3}\right), 20.99\left(\mathrm{CH}_{3}\right), 22.36\left(\mathrm{CH}_{3} \mathrm{x}\right), 30.09\left(\mathrm{CH}_{2}\right), 30.52\left(\mathrm{CH}_{2}\right), 38.23$ $\left(\mathrm{CH}_{2}\right), 42.81(\mathrm{CH}), 44.51(\mathrm{CH}), 47.82(\mathrm{C}), 47.90(\mathrm{CH}), 49.63(\mathrm{C}), 51.76(\mathrm{CH}), 59.13(\mathrm{CH})$, $64.73\left(\mathrm{CH}_{2}\right), 129.16(\mathrm{CHx} 4), 135.79$ (C), 141.60 (C); HRMS (EI) Calcd for $\mathrm{C}_{21} \mathrm{H}_{30} \mathrm{OS}$ : M 330.2019. Found: 330.2013. Anal. Calcd for $\mathrm{C}_{21} \mathrm{H}_{30} \mathrm{OS}$ : C, 76.31; H, 9.15. Found: C, 76.19; H, 9.21 .

Preparation of sulfonium salt (7). Typical procedure. To an acetone solution $(3 \mathrm{~mL})$ of sulfide 1 (0.30 mmol, $0.099 \mathrm{~g})$ was successively added benzyl bromide $(0.33 \mathrm{mmol}, 0.039 \mathrm{~g})$ and silver perchlorate $(0.33 \mathrm{mmol}, 0.0684 \mathrm{~g})$. The mixture was stirring at $\mathrm{rt}$ for $0.5-1 \mathrm{~h}$ and then dichloromethane $(20 \mathrm{~mL})$ was added to filter insoluble materials. The filtrate was evaporated and the residual fine crystals were washed with dry diethyl ether-hexane to give sulfonium perchlorate $7 \mathrm{a}$ as colorless fine crystals (70 \% yield). In the preparation of the other sulfonium salts $7 \mathbf{b}-\mathbf{e}$, evaporation of the filtrate gave viscous oil, which was then treated with hexane to solidify, followed by recrystallization from diethyl ether to give pure 7b-e for the epoxidation. Sulfonium bromide 7d was not sufficiently stable to allow NMR measurement.

Sulfonium perchlorate (7a). Colorless needles, $\mathrm{mp}$ (dec.) 207.9-208.4 ${ }^{\mathrm{O}} \mathrm{C}$, IR ( $\mathrm{KBr}$ disk, $\mathrm{cm}^{-1}$ ) 3468, 2920, 1440 and 1072; ${ }^{1} \mathrm{H}-\mathrm{NMR}\left(500 \mathrm{MHz}, \mathrm{CD}_{3} \mathrm{CN}\right) \delta 0.85(3 \mathrm{H}, \mathrm{s}), 1.05(3 \mathrm{H}, \mathrm{s}), 1.11-1.13$ $(1 \mathrm{H}, \mathrm{m}), 1.25(3 \mathrm{H}, \mathrm{s}), 1.51-1.52(1 \mathrm{H}, \mathrm{m}), 1.57-1.68(3 \mathrm{H}, \mathrm{m}), 2.33(3 \mathrm{H}, \mathrm{s}), 2.44-2.48(1 \mathrm{H}, \mathrm{m})$, $2.75(1 \mathrm{H}, \mathrm{dd}, 9.5,13.1), 2.88(1 \mathrm{H}, \mathrm{dd}, 11.3,13.1), 3.17(1 \mathrm{H}, \mathrm{dd}, 5.2,9.5), 3.30(1 \mathrm{H}, \mathrm{dd}, 5.2$, 10.7), 3.32 (1H, dd, 4.9, 13.4), $3.78(1 \mathrm{H}, \mathrm{dd}, 7.0,13.4), 4.14(1 \mathrm{H}, \mathrm{d}, 9.5), 4.71(1 \mathrm{H}, \mathrm{d}, 12.8), 4.86$ $(1 \mathrm{H}, \mathrm{d}, 12.8), 7.11-7.14(5 \mathrm{H}, \mathrm{m}), 7.44-7.49(2 \mathrm{H}, \mathrm{m}), 7.52-7.55(2 \mathrm{H}, \mathrm{m}) ;{ }^{13} \mathrm{C}-\mathrm{NMR}(125 \mathrm{MHz}$, $\left.\mathrm{CD}_{3} \mathrm{CN}\right) \delta 14.18,21.02,21.48,28.98,36.40,37.25,39.26,44.34,47.94,48.65,49.43,50.71$, $51.32,66.05,70.10,72.97,127.55 \times 2,127.73,128.35 \times 2,129.78 \times 2,130.60 \times 2,136.99,137.53$, 138.38. Anal. Calcd for $\mathrm{C}_{28} \mathrm{H}_{37} \mathrm{ClO}_{5} \mathrm{~S}$ : C, 64.54; H, 7.16. Found: C, 64.31; H, 7.22.

Sulfonium triflate (7b). Colorless solid; ${ }^{1} \mathrm{H}-\mathrm{NMR}\left(500 \mathrm{MHz}, \mathrm{CD}_{3} \mathrm{CN}\right) \delta 0.81(3 \mathrm{H}, \mathrm{s}), 0.86(3 \mathrm{H}$, s), 0.92-1.01 (1H, m), $1.16(3 \mathrm{H}, \mathrm{s}), 1.36-1.47(2 \mathrm{H}, \mathrm{m}), 1.60-1.67(2 \mathrm{H}, \mathrm{m}), 1.95-1.98(1 \mathrm{H}, \mathrm{m})$, 2.25 - $2.33(2 \mathrm{H}, \mathrm{m}) 2.31(3 \mathrm{H}, \mathrm{s}), 2.64(1 \mathrm{H}, \mathrm{dd}, 9.8,12.8), 2.78(1 \mathrm{H}, \mathrm{dd}, 11.3,12.8), 3.02(1 \mathrm{H}, \mathrm{dd}$, 6.1, 11.3), $3.54(1 \mathrm{H}, \mathrm{dd}, 6.1,13.4), 3.84(1 \mathrm{H}, \mathrm{d}, 9.8), 4.66(1 \mathrm{H}, \mathrm{d}, 12.8), 4.86(1 \mathrm{H}, \mathrm{d}, 12.8), 7.14-$ $7.18(4 \mathrm{H}, \mathrm{m}), 7.52-7.59(5 \mathrm{H}, \mathrm{m})$.

Sulfonium tetrafluoroborate (7c). Colorless needles; ${ }^{1} \mathrm{H}-\mathrm{NMR}\left(500 \mathrm{MHz}, \mathrm{CD}_{3} \mathrm{CN}\right) \delta 0.83(3 \mathrm{H}$, s), $0.93(3 \mathrm{H}, \mathrm{s}), 0.95-1.01(1 \mathrm{H}, \mathrm{m}), 1.19(3 \mathrm{H}, \mathrm{s}), 1.36-1.47(2 \mathrm{H}, \mathrm{m}), 1.58-1.73(2 \mathrm{H}, \mathrm{m}), 2.25(3 \mathrm{H}$, s), $2.65(1 \mathrm{H}, \mathrm{dd}, 9.6,12.9), 2.80(1 \mathrm{H}, \mathrm{dd}, 11.2,12.9), 3.16(2 \mathrm{H}, \mathrm{m}), 3.25(2 \mathrm{H}, \mathrm{m}), 3.40(1 \mathrm{H}, \mathrm{dd}$, 6.3, 13.5), $3.73(1 \mathrm{H}, \mathrm{d}, 9.6), 4.52(1 \mathrm{H}, \mathrm{d}, 13.0), 4.77(1 \mathrm{H}, \mathrm{d}, 12.9), 7.11(2 \mathrm{H}, \mathrm{d}, 8.1), 7.19(2 \mathrm{H}, \mathrm{d}$, $8.1), 7.52-7.58(5 \mathrm{H}, \mathrm{m})$. 
Sulfonium iodide (7e). Yellowish solid; ${ }^{1} \mathrm{H}-\mathrm{NMR}\left(500 \mathrm{MHz}, \mathrm{CD}_{3} \mathrm{CN}\right) \delta 0.75(3 \mathrm{H}, \mathrm{s}), 0.79(3 \mathrm{H}$, s), 1.11-1.22 (2H, m), $1.18(3 \mathrm{H}, \mathrm{m}), 1.47-1.65(3 \mathrm{H}, \mathrm{m}), 2.30(3 \mathrm{H}, \mathrm{s}), 2.68-2.85(2 \mathrm{H}, \mathrm{m}), 3.45-$ $3.50(2 \mathrm{H}, \mathrm{m}), 3.65-3.68(1 \mathrm{H}, \mathrm{m}), 3.77-3.80(1 \mathrm{H}, \mathrm{m}), 3.88-3.91(1 \mathrm{H}, \mathrm{m}), 4.04-4.06(1 \mathrm{H}, \mathrm{m}), 4.70-$ $4.95(2 \mathrm{H}, \mathrm{m}), 7.01-7.56(9 \mathrm{H}, \mathrm{m})$. Anal. Calcd for $\mathrm{C}_{28} \mathrm{H}_{37} \mathrm{IOS}$ : C, 61.31; H, 6.80. Found: C, 61.61; $\mathrm{H}, 7.03$.

Sulfonium perchlorate (9). Colorless needles, $\mathrm{mp}$ (dec.) 109.0-111.6 ${ }^{\circ} \mathrm{C}$; IR (KBr disk, $\mathrm{cm}^{-1}$ ) $3448,2920,1618,1442,1246,1072$ and $808 ;{ }^{1} \mathrm{H}-\mathrm{NMR}\left(500 \mathrm{MHz}, \mathrm{CD}_{3} \mathrm{CN}\right) \delta 0.89(3 \mathrm{H}, \mathrm{s}), 1.05-$ $1.13(1 \mathrm{H}, \mathrm{m}), 1.22(3 \mathrm{H}, \mathrm{s}), 1.29(3 \mathrm{H}, \mathrm{d}, 2.1), 1.31(3 \mathrm{H}, \mathrm{s}), 1.33(3 \mathrm{H}, \mathrm{d}, 2.1), 1.40(3 \mathrm{H}, \mathrm{d}, 1.7)$, $1.43(3 \mathrm{H}, \mathrm{d}, 1.7), 1.49(1 \mathrm{H}, \mathrm{d}, 1.8), 1.58-1.78(3 \mathrm{H}, \mathrm{m}), 2.33(3 \mathrm{H}, \mathrm{s}), 2.38-2.49(1 \mathrm{H}, \mathrm{m}), 2.69(1 \mathrm{H}$, dd, 9.7, 13.2), $2.97(1 \mathrm{H}, \mathrm{dd}, 11.4,13.2), 3.23(1 \mathrm{H}, \mathrm{dd}, 5.9,10.9), 3.31-3.33(2 \mathrm{H}, \mathrm{m}), 3.35-3.40$ $(1 \mathrm{H}, \mathrm{m}), 3.57-3.72(2 \mathrm{H}, \mathrm{m}), 3.85(1 \mathrm{H}, \mathrm{dd}, 4.6,13.0), 3.98(1 \mathrm{H}, \mathrm{dd}, 6.6,13.0), 4.09(1 \mathrm{H}, \mathrm{dd}, 4.6$, 14.2), 7.13-7.22 (4H, m); ${ }^{13} \mathrm{C}-\mathrm{NMR}\left(125 \mathrm{MHz}, \mathrm{CD}_{3} \mathrm{CN}\right) \delta 13.89,20.50,20.53,20.58,20.64$, $20.69,20.79,21.07,21.13,21.89,22.03,29.91,37.64,40.53,43.20,45.03,47.94,51.74,52.21$, $52.49,63.14,64.32,130.44,130.52 \times 3,138.04,139.82,162.49$.

Epoxidation using sulfonium salt [Method (A)]. A typical procedure (Table 6, Run a). - A mixture of benzaldehyde $(\mathbf{6 a})(0.05 \mathrm{mmol}, 0.0051 \mathrm{~mL})$, sulfonium perchlorate $7 \mathbf{a}(0.06 \mathrm{mmol}$, $0.0313 \mathrm{~g})$ and powdered $\mathrm{KOH}(0.06 \mathrm{mmol}, 0.0034 \mathrm{~g})$ in tert-butyl alcohol $(3 \mathrm{~mL})$ was stirred at $\mathrm{rt}$ for $48 \mathrm{~h}$. The reaction was quenched with water and the reaction mixture was extracted with dichloromethane $(10 \mathrm{~mL} \times 3)$. The combined extracts was washed with saturated aq. $\mathrm{NaCl}$ and dried over $\mathrm{MgSO}_{4}$. Evaporation of the solvent and column chromatography of the residue on silica gel $\left(40 \mathrm{~cm}^{3}\right)$ using EtOAc-hexane (1: 9) as an eluent gave 2,3-diphenyloxirane (8a) in 85 $\%$ yield in a trans:cis-isomers ratio of $94: 6$ with $69 \%$ ee of trans isomer. The other epoxidation reactions were similarly carried out under the conditions stated in corresponding Tables and runs. One-pot epoxidation [Method (B)]. A typical procedure (Table 11, Run b). - A mixture of $p$ nitrobenzaldehyde $(6 \mathbf{b})(0.10 \mathrm{mmol}, 0.0151 \mathrm{~g})$, benzyl bromide $(0.30 \mathrm{mmol}, 0.036 \mathrm{~mL})$, chiral sulfide $1(0.10 \mathrm{mmol}, 0.0331 \mathrm{~g})$ and powdered $\mathrm{K}_{2} \mathrm{CO}_{3}(0.30 \mathrm{mmol}, 0.042 \mathrm{~g})$ in tert-butyl alcohol $(5 \mathrm{~mL})$ was stirred at $\mathrm{rt}$ for $\mathbf{1} \mathrm{h}$. The work-up similar to that described above in Method (A) gave 2-(p-nitrophenyl)-3-phenyloxirane (8b) in $99 \%$ yield in a trans:cis ratio of 76:24 with $76 \%$ ee of trans-isomer.

Column chromatography conditions and chiral HPLC analyses conditions and data for various epoxides are listed below. 


\begin{tabular}{|c|c|c|c|c|c|c|c|c|}
\hline \multicolumn{3}{|c|}{ Column Chromatography } & \multicolumn{6}{|c|}{ HPLC data for epoxides } \\
\hline & Column & Eluent $^{a}$ & Coll & $\begin{array}{l}\mathrm{mn} \text { Eluent }^{\mathrm{a}} \\
(1.00 \mathrm{~mL} / \mathrm{min})\end{array}$ & Cis(major) & $\begin{array}{r}\text { Retenti } \\
\text { Cis(minor) }\end{array}$ & $\begin{array}{c}\text { on time / min } \\
\text { Trans(major) }\end{array}$ & Trans(minor) \\
\hline $\mathbf{8 a}$ & Silica gel & $\mathrm{E}: \mathrm{H}=1: 9$ & OD & $\mathrm{P}: \mathrm{H}=1: 100$ & 7.43 & - & 20.73 & 9.39 \\
\hline $\mathbf{8 b}$ & Silica gel & $\mathrm{E}: \mathrm{H}=1: 9$ & OD & $\mathrm{P}: \mathrm{H}=1: 30$ & 16.28 & 12.80 & 29.14 & 23.60 \\
\hline $8 c$ & Silica gel & $\mathrm{B}$ & OD & $\mathrm{P}: \mathrm{H}=1: 20$ & 6.07 & 6.07 & 8.09 & 7.32 \\
\hline 8d & Silica gel & $\mathrm{E}: \mathrm{H}=1: 20$ & OD & $\mathrm{P}: \mathrm{H}=1: 200$ & 13.06 & 13.06 & 31.24 & 16.05 \\
\hline $\mathbf{8 e}$ & Alumina & $\mathrm{E}: \mathrm{H}=1: 50$ & OD & $\mathrm{P}: \mathrm{H}=1: 50$ & 8.30 & 8.30 & 21.97 & 11.04 \\
\hline $8 f$ & Silica gel & $\mathrm{E}: \mathrm{H}=1: 9$ & OD & $\mathrm{Et}: \mathrm{H}=1: 50$ & 6.97 & 6.97 & 10.12 & 8.45 \\
\hline $8 g$ & Silica gel & $E: H=1: 9^{b}$ & $\mathrm{AD}$ & $\mathrm{Et}: \mathrm{H}=1: 20$ & 5.94 & 5.41 & 11.17 & 7.24 \\
\hline $\mathbf{8 h}$ & Alumina & $\mathrm{H}$ & OD & $\mathrm{Et}: \mathrm{H}=1: 300$ & 8.36 & 10.49 & 11.44 & 26.07 \\
\hline $\mathbf{8 i}$ & Alumina & $\mathrm{H}$ & OD & $\mathrm{Et}: \mathrm{H}=1: 300$ & 10.45 & 12.54 & 14.27 & 23.55 \\
\hline $\mathbf{8 j}$ & Silica gel & $\mathrm{E}: \mathrm{H}=1: 9$ & $\mathrm{AD}$ & $\mathrm{Et}: \mathrm{H}=1: 50$ & 13.87 & 15.14 & 22.69 & 39.36 \\
\hline $\mathbf{8 k}$ & Silica gel & $\mathrm{E}: \mathrm{H}=1: 9$ & OD & $\mathrm{Et}: \mathrm{H}=1: 50$ & 10.56 & 10.56 & 15.38 & 14.66 \\
\hline 10 & Silica gel & $\mathrm{E}: \mathrm{H}=1: 9$ & AS & $\mathrm{Et}: \mathrm{H}=1: 50$ & - & - & 19.82 & 25.61 \\
\hline
\end{tabular}

${ }^{\mathrm{a}} \mathrm{E}=$ ethyl acetate; $\mathrm{Et}=\mathrm{EtOH} ; \mathrm{H}=$ hexane; $\mathrm{P}=$ isopropyl alcohol; $\mathrm{B}=$ benzene. $^{\mathrm{b}}+5 \% \mathrm{Et}_{3} \mathrm{~N}$ was added.

2,3-Diphenyloxirane (8a). ${ }^{6,7 a, 9,10 a}$ Colorless solid; m.p. $66.0-67.0{ }^{\circ} \mathrm{C}$; $[\alpha]_{\mathrm{D}}-251$ (EtOH, c 5.82, $85 \%$ ee) (Calcd. -295); ${ }^{1} \mathrm{H}-\mathrm{NMR}\left(270 \mathrm{MHz}, \mathrm{CDCl}_{3}\right) \delta 3.86(2 \mathrm{H}, \mathrm{s}), 7.32$ - 7.37 (10H, m); MS (FAB) m/z $197\left(\mathrm{M}+\mathrm{H}^{+}, 82\right), 196\left(\mathrm{M}^{+}, 100\right)$; HRMS (EI) Calcd for $\mathrm{C}_{14} \mathrm{H}_{12} \mathrm{O}: \mathrm{M}$ 196.0888. Found: 196.0881 .

2-(p-Nitrophenyl)-3-phenyloxirane (8b). ${ }^{6,7 a, 9,10 a}$ Colorless solid; m.p. $125.5-128.7{ }^{\circ} \mathrm{C}$; $[\alpha]_{\mathrm{D}}$ $192\left(\mathrm{EtOH}, \mathrm{c} 1.013,74 \%\right.$ ee) (Calcd. -260); ${ }^{1} \mathrm{H}-\mathrm{NMR}\left(270 \mathrm{MHz}, \mathrm{CDCl}_{3}\right) \delta 3.85$ (1H, d, 1.65), $3.97(1 \mathrm{H}, \mathrm{d}, 1.65), 7.25(7 \mathrm{H}, \mathrm{m}), 8.23(2 \mathrm{H}, \mathrm{d}, 8.7)$; MS (FAB) $242\left(\mathrm{M}+\mathrm{H}^{+}, 23\right), 154(100), 136$ (100); HRMS (EI) Calcd for $\mathrm{C}_{14} \mathrm{H}_{11} \mathrm{NO}_{3}$ : M 241.0739. Found: 241.0743.

2-(4-Chlorophenyl)-3-phenyloxirane (8c). ${ }^{6,7 \mathrm{a}, 9,10 \mathrm{a}}$ Colorless solid; m.p. $89.5-91.3{ }^{\circ} \mathrm{C}$; $[\alpha]_{\mathrm{D}}-241$ (EtOH, c 1.020, 96 \%ee) (Calcd. -251); ${ }^{1} \mathrm{H}-\mathrm{NMR}\left(270 \mathrm{MHz}, \mathrm{CDCl}_{3}\right) \delta 3.80(1 \mathrm{H}, \mathrm{d}, 1.65), 3.83$ (1H, d, 1.65), 7.24-7.35 (9H, m).

2-Phenyl-3-tolyloxirane (8d). ${ }^{6,7 a, 9,10 a}$ Colorless solid; m.p. 57.5-59.1 ${ }^{\circ} \mathrm{C}$; $[\alpha]_{\mathrm{D}}-261(\mathrm{EtOH}$, c 1.867, $90 \%$ ee) (Calcd. -290) ${ }^{1} \mathrm{H}-\mathrm{NMR}\left(270 \mathrm{MHz}, \mathrm{CDCl}_{3}\right) \delta 2.37(3 \mathrm{H}, \mathrm{s}), 3.84(1 \mathrm{H}, \mathrm{d}, 1.9), 3.87$ (1H, d, 1.9), 7.18-7.39 (9H, m).

2-(Methoxyphenyl)-3-phenyloxirane (8e). ${ }^{6,10 \mathrm{a}}$ Colorless solid; m.p. 76.0-78.2 ${ }^{\circ} \mathrm{C}$; $[\alpha]_{\mathrm{D}}-94$ (EtOH, c 0.453, 41 \% ee) (Calcd. -229); ${ }^{1} \mathrm{H}-\mathrm{NMR}\left(270 \mathrm{MHz}, \mathrm{CDCl}_{3}\right) \delta 3.74(3 \mathrm{H}, \mathrm{s}), 3.77(1 \mathrm{H}, \mathrm{d}$, 1.98), 3.81 (1H, d, 1.98), 6.83-6.89 (2H, m), 7.20-7.24 (2H, m), 7.27-7.34 (5H, m).

2-Naphthyl-3-phenyloxirane (8f). ${ }^{6}$ Colorless solid; m.p. $120.7-121.2{ }^{\circ} \mathrm{C}$; $[\alpha]_{\mathrm{D}}-236\left(\mathrm{CHCl}_{3}, \mathrm{c}\right.$ 0.867, 97 \% ee) ( Calcd. -243).; ${ }^{1} \mathrm{H}-\mathrm{NMR}\left(270 \mathrm{MHz}, \mathrm{CDCl}_{3}\right) \delta 3.96(1 \mathrm{H}, \mathrm{d}, 1.8), 4.03(1 \mathrm{H}, \mathrm{d}$, 1.8),7.23-7.49 (8H, m), 7.75-7.83 (4H, m); MS (FAB) $247\left(\mathrm{M}+\mathrm{H}^{+}, 47\right), 154$ (100); HRMS (EI) Calcd for $\mathrm{C}_{18} \mathrm{H}_{14} \mathrm{O}$ : M 246.1045. Found: 246.1049. 
2-Phenyl-3- $\beta$-styryloxirane (8g). ${ }^{5 \mathrm{~d}, 6,10 \mathrm{a}}$ Colorless solid; m.p. $73.1-74.4{ }^{\circ} \mathrm{C} ;{ }^{1} \mathrm{H}-\mathrm{NMR}(270 \mathrm{MHz}$, $\left.\mathrm{CDCl}_{3}\right) \delta 3.52(1 \mathrm{H}, \mathrm{dd}, 1.71,7.81), 3.89(1 \mathrm{H}, \mathrm{d}, 1.71), 6.06(1 \mathrm{H}, \mathrm{dd}, 7.81,16.1), 6.82(1 \mathrm{H}, \mathrm{d}$, 16.1), 7.23-7.39 (8H, m), $7.66(2 \mathrm{H}, \mathrm{d}, 7.56)$.

2-Furyl-3-phenyloxirane (8h). ${ }^{6,7 \mathrm{~d}, 10 \mathrm{a}}$ Yellow oil; ${ }^{1} \mathrm{H}-\mathrm{NMR}\left(270 \mathrm{MHz}, \mathrm{CDCl}_{3}\right) \delta 3.87(1 \mathrm{H}, \mathrm{d}$, 2.0), 4.34 (1H, d, 2.0), $6.37(1 \mathrm{H}, \mathrm{dd}, 1.8,3.1), 6.47(1 \mathrm{H}, \mathrm{d}, 3.1), 7.11$ - $7.41(6 \mathrm{H}, \mathrm{m})$; MS (FAB) $\mathrm{m} / \mathrm{z} 187\left(\mathrm{M}+\mathrm{H}^{+}, 41\right), 105(100)$; HRMS (FAB) Calcd for $\mathrm{C}_{12} \mathrm{H}_{10} \mathrm{O}_{2} \mathrm{H}: \mathrm{M}+\mathrm{H}$ 187.0759. Found: 187.0758 .

2-Phenyl-3-thienyloxirane (8i). ${ }^{6,10 \mathrm{a}}$ Colorless oil; ${ }^{1} \mathrm{H}-\mathrm{NMR}\left(270 \mathrm{MHz}, \mathrm{CDCl}_{3}\right) \delta 4.03(1 \mathrm{H}, \mathrm{d}$, 1.3), 4.07 (1H, d, 1.3), 6.99 - 7.32 (8H, m); MS (FAB) $203\left(\mathrm{M}+\mathrm{H}^{+}, 100\right)$; HRMS (FAB) Calcd for $\mathrm{C}_{12} \mathrm{H}_{10} \mathrm{OSH}: \mathrm{M}+\mathrm{H}$ 203.0531. Found: 203.0531.

2-Phenyl-3-pyridyloxirane (8j). ${ }^{7 d, 10 a}$ Yellow oil; $[\alpha]_{\mathrm{D}}-140\left(\mathrm{CHCl}_{3}, \mathrm{c} 0.55,55 \%\right.$ ee) (Calcd. 252); ${ }^{1} \mathrm{H}-\mathrm{NMR}\left(270 \mathrm{MHz}, \mathrm{CDCl}_{3}\right) \delta 4.05(1 \mathrm{H}, \mathrm{d}, 1.9), 4.07(1 \mathrm{H}, \mathrm{d}, 1.9), 7.23-7.39$ (7H, m), 7.71 (1H, ddd, 1.8, 7.8, 7.8), 8.59 (1H, ddd, 0.83, 0.83, 4.8).

2-(o-Benzyloxy)-3-phenyloxirane (8k). Colorless solid; m.p. 64.0-65.8 ${ }^{\circ} \mathrm{C} ;[\alpha]_{\mathrm{D}}-27(\mathrm{EtOH}, \mathrm{c}$ 3.107, $47 \%$ ee) (Calcd. -57); IR (KBr disk, $\mathrm{cm}^{-1}$ ) 2992,1582, 1448, 1368, 1222, 1102, 1008, 844, 728 and 692; ${ }^{1} \mathrm{H}-\mathrm{NMR}\left(270 \mathrm{MHz}, \mathrm{CDCl}_{3}\right) \delta 3.79(1 \mathrm{H}, \mathrm{d}, 1.98), 4.30(1 \mathrm{H}, \mathrm{d}, 1.98), 5.05(2 \mathrm{H}, \mathrm{s})$, $6.89(1 \mathrm{H}, \mathrm{d}, 8.25), 6.97(1 \mathrm{H}, \mathrm{dd}, 7.43,7.43), 7.21-7.34(12 \mathrm{H}, \mathrm{m}) ;{ }^{13} \mathrm{C}-\mathrm{NMR}\left(67.8 \mathrm{MHz}, \mathrm{CDCl}_{3}\right)$ $\delta 58.44,62.05,69.94,111.82,121.02,125.18,125.64(\mathrm{x} 2), 126.21,126.80(\mathrm{x} 2), 127.68,128.07$, 128.39 (x4), 128.82, 136.80, 137.30, 157.02; MS (FAB) m/z 303 (M+H', 7), 91 (100); HRMS (FAB) Calcd for $\mathrm{C}_{28} \mathrm{H}_{18} \mathrm{O}_{2} \mathrm{H}: \mathrm{M}+\mathrm{H}$ 303.1385. Found: 303.1383.

2-( $N, N$-Diisopropylcarbamoyl)-3-(4-nitrophenyl)oxirane (10). Colorless solid; m.p. 98.4-99. $6{ }^{\circ} \mathrm{C}$; $[\alpha]_{\mathrm{D}}-8.64\left(\mathrm{CHCl}_{3}, \mathrm{c} 2.40,73 \%\right.$ ee) (Calcd. -11.68); IR (KBr disk, $\left.\mathrm{cm}^{-1}\right)$ 2932, 1636, 1598, 1516, 1430, 1300, 1206, 1102, 1040 and 832; ${ }^{1} \mathrm{H}-\mathrm{NMR}\left(270 \mathrm{MHz}, \mathrm{CDCl}_{3}\right) \delta 1.27(3 \mathrm{H}, \mathrm{d}, 6.6), 1.30$ $(3 \mathrm{H}, \mathrm{d}, 6.8), 1.40(3 \mathrm{H}, \mathrm{d}, 6.8), 1.41(3 \mathrm{H}, \mathrm{d}, 6.6), 3.56(1 \mathrm{H}, \mathrm{d}, 2.0), 3.71(1 \mathrm{H}, \mathrm{sept}, 6.8), 4.14(1 \mathrm{H}$, sept, 6.6), $4.22(1 \mathrm{H}, \mathrm{d}, 2.0), 7.51(2 \mathrm{H}, \mathrm{d}, 8.3), 8.23(2 \mathrm{H}, \mathrm{d}, 8.3) ;{ }^{13} \mathrm{C}-\mathrm{NMR}\left(67.8 \mathrm{MHz}, \mathrm{CDCl}_{3}\right) \delta$ $20.16\left(\mathrm{CH}_{3}\right), 20.31\left(\mathrm{CH}_{3}\right), 21.34\left(\mathrm{CH}_{3} \mathrm{x}\right), 46.28(\mathrm{CH}), 47.85(\mathrm{CH}), 56.60(\mathrm{CH}), 59.49(\mathrm{CH})$, 123.92 (CHx2), 126.42 (CHx2), 143.39 (C), 148.04 (C), 164.36 (C); MS (FAB) m/z 293 (M+H', 79), 86 (100); HRMS (FAB) Calcd for $\mathrm{C}_{15} \mathrm{H}_{20} \mathrm{~N}_{2} \mathrm{O}_{4} \mathrm{H}$ : $\mathrm{M}+\mathrm{H}$ 293.1501. Found: 293.1501. Anal. Calcd for $\mathrm{C}_{15} \mathrm{H}_{20} \mathrm{~N}_{2} \mathrm{O}_{4}$ : C, 61.63; H, 6.90; N, 9.58. Found: C, 61.41; H, 7.14; N, 9.31.

\section{Acknowledgments}

This work supported in part by a Grant-in-Aid for Scientific Research from the Ministry of Education, Culture, Sports, Science and Technology, Japan.

\section{References and Notes}

1. (a) Bartók, M.; Láng, K. L. In The Chemistry of Functional Groups, Supplement E, Patai, S. Ed.; Wiley: New York, 1980, p 609. (b) Satoh; T. Chem. Rev. 1996, 96, 3303. (c) Rao, A. S. 
In Comprehensive Organic Synthesis, Trost, B. M.; Fleming, I. Eds; Pergamon Press: Oxford, 1991; Vol. 7, p 357. (d) Aube, J. In Comprehensive Organic Synthesis, Trost, B. M.; Fleming, I. Eds.; Pergamon Press: Oxford, 1991; Vol. 1, p 819. (e) Collman, J. P.; Zhang, X.; Lee, V. J.; Uffelman, E. S.; Brauman, J. I. Science 1993, 261, 1404.

2. (a) Katsuki, T., In Comprehensive Asymmetric Catalysis; Jacobsen, E. N.; Pfaltz, A.; Yamamoto, H. Eds.; Springer Verlag: Heidelberg, 1999; Vol. II, p 621. (b) Jacobsen, E. N., In Catalytic Asymmetric Synthesis, Ojima, I. Ed; VCH: New York, 1993, p 159. (c) Johnson R. A.; Sharpless, K. B., In Comprehensive Organic Synthesis, Trost, B. M.; Fleming, I. Eds.; Pergamon Press: Oxford, 1991; Vol. 7, p 389. (d) Rosen, T., In Comprehensive Organic Synthesis, Trost, B. M. Fleming, I. Eds.; Pergamon Press: Oxford, 1991; Vol. 2, p 409.

3. Corey, E. J.; Chaykovsky, M., J. Am. Chem. Soc. 1965, 87, 1353.

4. (a) Li, A.-H.; Dai, L.-X.; Aggarwal, V. K. Chem. Rev. 1997, 97, 2341. (b) Aggarwal, V. K. Synlett. 1998, 329, and references cited therein.

5. (a) Zhou, Y.-G.; Hou, X.-L.; Dai, L.-X.; Xia, L.-J.; Tang, M.-H. J. Chem. Soc., Perkin Trans. 1, 1999, 77. (b) Dai, L.-X.; Lou, B.-L.; Zhang, Y.-Z. J. Am. Chem. Soc. 1988, 110, 5915. (c) Li, A.-H.; Dai, L.-X.; Hou, X.-L.; Huang, Y.-Z.; Li, F.-W. J. Org. Chem. 1996, 61, 489. (d) Frohn, M.; Dalkiewicz, M.; Tu, Y.; Wang, Z.-X.; Shi, Y. J. Org. Chem. 1998, 63, 2948.

6. (a) Julienne, K.; Metzner, P.; Henryon, V. J. Chem. Soc., Perkin Trans. 1 1999, 731. (b) Julienne, K.; Metzner, P. J. Org. Chem. 1998, 63, 4532. (c) Zanardi, J.; Leriverend, C.; Aubert, D.; Julienne, K.; Metzner, P. Henryon, V.; Greiner, A. J. Org. Chem. 2001, 66, 5620 .

7. (a) Solladié-Cavallo, A.; Diep-Vohuule, A.; Sunjic, A.; Vinkovic, V. Tetrahedron: Asymmetry 1996, 7, 1783. (b) Solladié-Cavallo, A.; Diep-Vohuule, A. J. Org. Chem. 1995, 60, 3494. (c) Solladié-Cavallo, A.; Bouérat, L.; Roje, M. Tetrahedron Lett. 2000, 41, 7309. (d) Solladié-Cavallo, A.; Roje, M.; Isarno, T.; Sunjic, V.; Vinkovic, V. Eur. J. Org. Chem. 2002, 1077.

8. Durst, T; Breau, L; Ben, R. N. Phosphorus Sulfur \& Relat. Elem. 1993, 74, 215.

9. Furukawa, N.; Sugihara, Y.; Fujihara, H. J. Org. Chem. 1989, 54, 4222.

10. (a) Aggarwal, V. K.; Alonso, E.; Bae, I.; Hynd, G.; Lydon, K. M.; Palmer, M. J.; Patel, M.; Porcelloni, M.; Richardson, J.; Stenson, P. A.; Studley, J. R.; Vasse, J.-L.; Winn, C. L. J. Am. Chem. Soc. 2003, 125, 10926. (b) Aggarwal, V. K.; Alonso, E.; Hynd, G.; Lydon, K. M.; Palmer, M. J.; Porcelloni, M.; Studley, J. R. Angew. Chem. Int. Ed. Engl. 2001, 40, 1430. (c) Aggarwal, V. K.; Ford, J. G.; Thompson, A.; Jones, R. V. H.; Standen, M. C. H. J. Am. Chem. Soc. 1996, 118, 704. (d) Aggarwal, V. K.; Ford, J. G.; Fonquerna, S.; Adams, H.; Jones, R. V. H.; Fieldhouse, R. J. Am. Chem. Soc. 1998, 120, 8328. (e) Aggarwal, V. K.; Ford, J. G.; Jones, R. V. H.; Fieldhouse, R. Tetrahedron: Asymmetry 1998, 9, 1801.

11. (a) Winn, C. L.; Bellenie, B. R.; Goodman, J. M. Tetrahedron Lett. 2002, 43, 5427. (b) Myllymäki, V. T.; Lindvall, M. K.; Koskinen, A. M. P. Tetrahedron 2001, 57, 4629. (c) Aggarwal, V. K.; Angelaud, R.; Bihan, D.; Blackburn, P.; Fieldhouse, R.; Fonquerna, S. J.; Ford, G. D.; Hynd, G.; Jones, E.; Jones, R. V. H.; Jubault, P.; Palmer, M. J.; Ratcliffe, R. D.; 
Adams, H. J. Chem. Soc., Perkin Trans. 1 2001, 2604. (d) Hayakawa, R.; Shimizu, M. Synlett 1999, 1328. (e) Imashiro, R.; Yamanaka, T.; Seki, M. Tetrahedron: Asymmetry 1999, 10, 2845.

12. (a) Saito, T.; Sakairi, M.; Akiba, D. Tetrahedron Lett. 2001, 42, 5451. (b) Aggarwal, V. K.; Alonso, E.; Fang, G.; Ferrara, M.; Hynd, G.; Porcelloni, M. Angew. Chem. Int. Ed. Engl. 2001, 40, 1433. (c) Aggarwal, V. K.; Ferrara, M.; O’Brien, C. J.; Thompson, A.; Jones, R. V. H.; Fieldhouse, R. J. Chem. Soc., Perkin Trans. 1 2001, 1635. (d) Aggarwal, V. K.; Thompson, A.; Jones, R. V. H.; Standen, M. C. H. J. Org. Chem. 1996, 61, 8368. (e) Li, A.H.; Zhou, Y.-G.; Dai, L.-X.; Hou, X.-L.; Xia, L.-J.; Lin, L. J. Org. Chem. 1998, 63, 4338.

13. (a) Ye, S.; Huang, Z.-Z.; Xia, C.-A.; Tang, Y.; Dai, L.-X. J. Am. Chem. Soc. 2002, 124, 2432. (b) Aggarwal, V. K.; Smith, H. W.; Hynd, G.; Jones, R. V. H.; Fieldhouse, R.; Spey, S. J. Chem. Soc., Perkin Trans. 1 2000, 3264. (c) Mamai, A.; Madalengoitia, J. S. Tetrahedron Lett. 2000, 41, 9009. (d) Solladié-Cavallo, A.; Diep-Vohuule, A. Angew. Chem. Int. Ed. Engl. 1998, 37, 1689.

14. (a) Aggarwal, V. K.; Harvey, J. N.; Richardson, J. J. Am. Chem. Soc. 2002, 124, 5747. (b) Lindvall, M. K.; Koskinen, A. P. M. J. Org. Chem. 1999, 64, 4596. (c) Kawashima, T.; Ohno, F.; Okazaki, R.; Ikeda, H.; Inagaki, S. J. Am. Chem. Soc. 1996, 118, 12455. (d) Volatron, F.; Eisenstein, O. J. Am. Chem. Soc. 1987, 109, 1.

15. (a) Morrison, J. D., Ed.; Asymmetric Synthesis; 1983, Vol.2 and 1985, Vol. 5. (b) Money, T. Natural Prod. Reports 1985, p 253. (c) Oppolzer, W. Tetrahedron 1987, 43, 1969. (d) Blaser, H.-U. Chem. Rev. 1992, 92, 935. (e) Uang, B.-J.; Po, S.-C.; Hung, S.-C.; Liu, H.-H.; Hsu, C.-Y.; Lin, Y.-S.; Chang, J.-W. Pure Appl. Chem. 1997, 69, 615. (f) Arai, Y. Koizumi, T. Sulfur Reports 1993, 15, 41. Related recent literature: e.g., (g) Chu, Y.-Y.; Yu., C.-S.; Chen, C.-J.; Yang, K.-S.; Lain, J.-C.; Lin, C.-H.; Chen, K. J. Org. Chem. 1999, 64, 6993. (h) McNulty, J.; Millar, M. J. J. Org. Chem. 1999, 64, 5312. (i) Verdaguer, X.; Vázquez, J.; Fuster, G.; Bernardes-Génisson, V.; Greene, A. E.; Moyano, A.; Percàs, M. A.; Riera, A. J. Org. Chem. 1998, 63, 7037. (j) de Vries, A. H. M.; Imbos, R.; Feringa, B. L. Tetrahedron: Asymmetry 1997, 8, 1467. (k) Tanaka, K.; Matsui, J.; Suzuki, H. J. Chem. Soc., Perkin Trans. 1 1993, 153. (1) Salama, P.; Poirier, M.; Maya, M. del R. P.; Robichaud, J.; Benoit, M. Synlett 1996, 823. Salama, P.; Poitrier, M. Tetrahedron: Asymmetry 1997, 8, 2757. (m) Bonnat, M.; Durand, J.-O; Corre, M. L. Tetrahedron: Asymmetry 1996, 7, 559. (n) Sewald, N; Wendisch, V. Tetrahedron: Asymmetry 1996, 7, 1269. (o) Watson, A. A.; House, D. A; Steel, P. J. J. Org. Chem. 1991, 56, 4072. (p) Brunner, H.; Scheck, T. Chem. Ber. 1992, 125 , 701. (q) Morris, D. G.; Ryder, K. S. Synthesis 1997, 620. (r) Palomo, C.; Berrée, F.; Linden, A.; Villagordo, J. M. J. Chem. Soc., Chem. Commun. 1994, 1861. (s) Kouklovsky, C.; Pouilhès, A.; Langlois, Y. J. Am. Chem. Soc. 1990, 112, 6672.

16. Saito, T.; Akiba, D,; Sakairi, M.; Kanazawa, S. Tetrahedron Lett. 2001, $42,57$.

17. (a) Saito, T.; Nishimura, J.; Akiba, D.; Kusuoku, H.; Kobayashi, K. Tetrahedron Lett. 1999, 40, 8383. (b) Saito, T.; Furuie, H.; Ishigo-oka, Y.; Watanabe, I. Heterocycles 2000, 53, 1685.

18. Aggarwal pointed out this tendency in sulfonium ylide-mediated carbonyl epoxidation. ${ }^{10 a}$ 